\title{
The borage family (Boraginaceae s.str.): A revised infrafamilial classification based on new phylogenetic evidence, with emphasis on the placement of some enigmatic genera
}

Juliana Chacón, ${ }^{1}$ Federico Luebert, ${ }^{1,2}$ Hartmut H. Hilger, ${ }^{3}$ Svetlana Ovchinnikovaa ${ }^{4}$ Federico Selvi, Lorenzo Cecchi, ${ }^{6}$ C. Matt Guilliams, ${ }^{7}$ Kristen Hasenstab-Lehman, ${ }^{8}$ Karel Sutorý, ${ }^{9}$ Michael G. Simpson ${ }^{10}$ \& Maximilian Weigend ${ }^{1}$

1 Universität Bonn, Nees-Institut für Biodiversität der Pflanzen, Meckenheimer Allee 170, 53115 Bonn, Germany

2 Universidad de Chile, Departamento de Silvicultura y Conservación de la Naturaleza, Santiago, Chile

3 Freie Universität Berlin, Institut für Biologie-Botanik, Altensteinstr. 6, 14195 Berlin, Germany

4 Central Siberian Botanical Garden, SB RAS, Zolotodolinskaya str. 101, 630090 Novosibirsk, Russia

5 Università di Firenze, Dipartimento di Scienze delle Produzioni Agroalimentari e dell'Ambiente (DISPAA), Laboratorio di

Botanica, P. le delle Cascine 28, 50144 Florence, Italy

6 Università di Firenze, Museo di Storia Naturale, sezione botanica "Filippo Parlatore”, via G. La Pira 4, 50121 Florence, Italy

7 Santa Barbara Botanic Garden, 1212 Mission Canyon Road, Santa Barbara, California, 93105, U.S.A.

8 Rancho Santa Ana Botanic Garden, 1500 N College Ave, Claremont, California, 91711, U.S.A.

9 Department of Botany, Moravian Museum, Hviezdoslavova 29a, 62700 Brno, Czech Republic

10 Department of Biology, San Diego State University, San Diego, California 92182, U.S.A.

Author for correspondence: Maximilian Weigend, mweigend@uni-bonn.de

ORCID JC, http://orcid.org/0000-0003-3993-2553; FL, http://orcid.org/0000-0003-2251-4056; SO, http://orcid.org/0000-0002-3876-954X; FS, http://orcid.org/0000-0002-3820-125X; LC, http://orcid.org/0000-0002-9332-704X; CMG, http://orcid.org/0000-0003-3919-8432; MGS, http://orcid.org/0000-0002-6197-2132; MW, http://orcid.org/0000-0003-0813-6650

DOI http://dx.doi.org/10.12705/653.6

Abstract Boraginaceae s.str. is a subcosmopolitan family of 1600 to 1700 species in around 90 genera, and recent phylogenetic studies indicate that the infrafamilial classification as currently used is highly obsolete. The present study addresses the relationships of the major clades in Boraginaceae s.str. with an emphasis on monophyly of, and relationships between previously recognized clades and the position of various unplaced genera such as Afrotysonia, Anoplocaryum, Brachybotrys, Chionocharis, Craniospermum, Thyrocarpus, and Trigonocaryum using three plastid markers and a taxon sampling with four outgroup and 170 ingroup species from 73 genera. The phylogeny shows high statistical support for most nodes on the backbone and within individual clades. Echiochileae are confirmed as sister to the remainder of Boraginaceae s.str., which, in turn, fall into two well-supported clades, the Boragineae+Lithospermeae and the Cynoglosseae s.l. The latter is highly resolved and includes the Lasiocaryum-clade (Chionocharis, Lasiocaryum, Microcaryum) and the Trichodesmeae (Caccinia, Trichodesma) as sister to the remainder of the group. Rochelieae (formerly the Eritrichieae s.str., also including Eritrichium, Hackelia, and Lappula) form a poorly supported polytomy together with the Mertensia-clade (also including Anoplocaryum, Asperugo, and Memoremea) and the Omphalodesclade. The enigmatic genus Craniospermum (Craniospermeae) is sister to an expanded Myosotideae (also including Brachybotrys, Decalepidanthus, Trigonocaryum, and Trigonotis) and these two clades are in turn sister to the Core-Cynoglosseae, in which Afrotysonia glochidiata and Thyrocarpus sampsonii are included. Core-Cynoglosseae again fall into two pairs of well-supported subclades. The majority of generic placements are now resolved satisfactorily and the remaining phylogenetic questions can be clearly delimited. Based on the extensive phylogenetic data now available we propose a new infrafamilial classification into three subfamilies and 11 tribes, representing a consensus among the participating authors, according to which major clades are renamed.

Keywords Boraginaceae s.str.; Cynoglosseae s.l.; monophyly; new ranks; tribal classification; unplaced genera

Supplementary Material Electronic Supplement (Fig. S1) and DNA sequence alignment are available in the Supplementary Data section of the online version of this article at http://ingentaconnect.com/content/iapt/tax

\section{INTRODUCTION}

The systematics and classification of the borage family (= Boraginaceae s.str., Fig. 1; see Weigend \& al., 2013, 2014; Cohen, 2014; Refulio-Rodriguez \& Olmstead, 2014; Luebert
\& al., 2016; also summarized in Stevens, 2001-) has intrigued botanists for many years. Weigend \& al. (2014) place this clade in the order Boraginales, sister to Wellstediaceae. This circumscription of Boraginaceae is different from the proposal by APG III (2009), which treats Boraginaceae in a wider

Received: 16 Oct 2015 | returned for (first) revision: 12 Jan 2016 | (last) revision received: 19 Feb 2016 | accepted: 22 Feb 2016 || publication date(s): online fast track, n/a; in print and online issues, 24 Jun 2016 || (C) International Association for Plant Taxonomy (IAPT) 2016 
sense, including several taxa here recognized at the family level (Codonaceae, Cordiaceae, Ehretiaceae, Heliotropiaceae, Hoplestigmataceae, Hydrophyllaceae, Lennoaceae, Wellstediaceae) and formally treated in Luebert \& al. (2016). However, an infrafamilial classification representing monophyletic subdivisions of the Boraginaceae s.str. (henceforth referred to as Boraginaceae) is still needed. A widely accepted classification based on morphological characters of the flowers and nutlets recognizes four to seven tribes: Boragineae Rchb., Cynoglosseae W.D.J.Koch, Eritrichieae Gürke, Lithospermeae Dumort. (Johnston, 1924), expanded with Trichodesmeae Zakirov ex Riedl, Myosotideae Rchb.f., and Trigonotideae Riedl (Riedl, 1967, 1997). Nevertheless, recent molecular studies have demonstrated that this subdivision is inconsistent with evolutionary history, as nearly half of the tribes sensu Riedl (1967, i.e., Eritrichieae, Myosotideae, and Trigonotideae) are embedded in Cynoglosseae s.l. (Weigend \& al., 2010, 2013). Only four lineages seem to be strongly supported by both molecular and morphological characters (Långström \& Chase, 2002; Weigend \& al., 2013), namely the Boragineae, Echiochileae Långström $\&$ M.W.Chase, Lithospermeae, and Cynoglosseae s.l. A comprehensive resolution of the Cynoglosseae s.l. into six wellsupported clades was achieved in the study by Weigend \& al. (2013). Interestingly, many genera, such as Omphalodes Moench and Cynoglossum L., were retrieved as either poly- or paraphyletic, indicating that the morphological characters used in traditional taxonomic classifications are highly homoplasious (Weigend \& al., 2013). Some of the taxonomic problems arising from the polyphyly of Omphalodes have been addressed by Otero \& al. (2014), who created the genera Memoremea A.Otero \& al. and Nihon A.Otero \& al. to accommodate some outliers of Omphalodes. Similarly, polyphyly of Cynoglossum has recently been reduced through the institution of two new genera for the North American species, which were formerly included in Cynoglossum but are distant to the typical EuroMediterranean species (Cohen, 2015). Morphological characters lacking diagnostic value hamper the systematic placement of genera with aberrant morphologies. Many of these genera have fewer than six species restricted to narrow geographic ranges and have never been analyzed in a phylogenetic context. Therefore, the use of molecular tools in elucidating their phylogenetic affinities needs to be considered, as this will ultimately help to unravel their relationships.
Among the unplaced genera of the Boraginaceae are Afrotysonia Rauschert, Anoplocaryum Ledeb., Craniospermum Lehm., and Thyrocarpus Hance. Afrotysonia comprises three species of tall perennial herbs endemic to South Africa and Tanzania (Verdcourt, 1991). In his original description of the genus (as Tysonia Bolus) Bolus (1890) related it to the West Asian-East European genera Caccinia Savi, Solenanthus Ledeb., and Rindera Pall., and mentioned striking resemblances with the habit, leaves, and fruit shape of the New Zealand (Chatham Island) Myosotidium Hook. Mill (1986) proposed that Afrotysonia is closely allied to the African+Asian Paracynoglossum Popov, with which it shares a pollen type with similar oblong shape, dismissing the generic affinities proposed by Bolus (1890). Other geographically restricted taxa that have flowers and nutlets similar to those of Afrotysonia are the Mediterranean-West Asian Lindelofia Lehm., Mattiastrum (Boiss.) Brand, Paracaryum Boiss., Trachelanthus Kunze, and the American monospecific Dasynotus I.M.Johnst. (Weigend $\&$ al., 2016). All of them are part of the Core-Cynoglosseae (Weigend \& al., 2013), suggesting that Afrotysonia also belongs in this clade.

Another problematic taxon of the Cynoglosseae is the Central Asian Anoplocaryum (Fig. 1G), with five species of annual and perennial, subglabrous plants that grow in shady damp crevices and under granite rocks (Popov, 1953; Ovchinnikova, 2013). Johnston (1924) suggested that Anoplocaryum and Mertensia Roth are close allies differing only in the shape of the corolla and the attachment of the nutlet. Ovchinnikova (2007, 2009) placed it in the subtribe Anoplocaryinae Ovchinnikova (Eritrichieae) and, according to her inference of evolutionary relationships among genera, predicted some phylogenetic relationships with Trigonotis Steven and Asperugo L.

The enigmatic Craniospermum is another example of an aberrant taxon of unknown affinities (Fig. 1M, N). It includes four to six species of biennial or perennial herbs distributed in East Asia (Johnston, 1924; Zhu \& al., 1995; Ovchinnikova, 2000, 2001). Popov (1953) placed this genus in its own monogeneric tribe Craniospermeae DC. ex Meisn., and this was taken up by Ovchinnikova (2009) based on analyses of palynological and fruit characters. Moreover, Ovchinnikova's study suggested that Craniospermum originated after hybridization of Trichodesma R.Br. with "uncertain partners" in Central Asia (Ovchinnikova, 2009) because these two genera, as well as

Fig. 1. Morphological diversity in Boraginaceae. A, Boragineae (Moritzia ciliata DC. ex Meisn., photo: C. Schlindwein, Brazil); B, Lithospermeae (Onosma alborosea Fisch. \& C.A.Mey., photo \& coll.: M. Weigend 9450); C \& D, Lasiocaryum-clade (C, Chionocharis hookeri, photo \& coll.: D. Boufford 31100; D, Lasiocaryum trichocarpum (Hand.-Mazz.) I.M.Johnst., photo \& coll.: D. Boufford 42157); E \& F, Trichodesmeae (E, Trichodesma zeylanicum (Burm.f.) R.Br., photo: M. Ackermann, Bonn University Botanic Gardens; F, Caccinia macranthera (Banks \& Sol.) Brand, photo \& coll.: O. Mohr 592); G-I, Mertensia-clade (G, Anoplocaryum compressum (Turcz.) Ledeb., photo \& coll.: H.H. Hilger 1609; H, Asperugo procumbens, photo: O. Mohr, Berlin; I, Mertensia bakeri Greene, photo \& coll.: M. Weigend 9344); J \& K, Omphalodes-clade (J, Myosotidium hortensia (Decne.) Baill., photo \& coll.: M. Weigend 9086; K, Omphalodes verna Moench, photo: M. Ackermann, Bonn); L, Eritrichieae s.str. (Eritrichium aretioides (Cham.) A.DC., photo \& coll.: M. Weigend 9126); M \& N, Craniospermeae (M, Craniospermum mongolicum I.M.Johnst, photo: P. Kosachev, http://www.plantarium.ru/page/image/id/128251.html); N, Craniospermum subvillosum Lehm., photo: N. Stepantsova, http:// www.plantarium.ru/page/image/id/240836.html); O \& P, Myosotideae (0, Decalepidanthus primuloides (Decne.) Dickoré \& Hilger, photo \& coll.: M. Ackermann s.n.; P, Myosotis alpestris F.W.Schmidt, photo: E. Scherer); Q \& R, Cryptantha-clade (Q, Amsinckia vernicosa Hook. \& Arn., photo \& coll.: M. Weigend 9008; R, Cryptantha virginensis (M.E.Jones) Payson, photo: M. Weigend, Bonn); S \& T, Cynoglossum s.l. (S, Solenanthus apenninus Hohen, photo \& coll.: Weigend 8139; T, Trachelanthus cerinthoides Kunze, photo: W. Lobin, Bonn). 

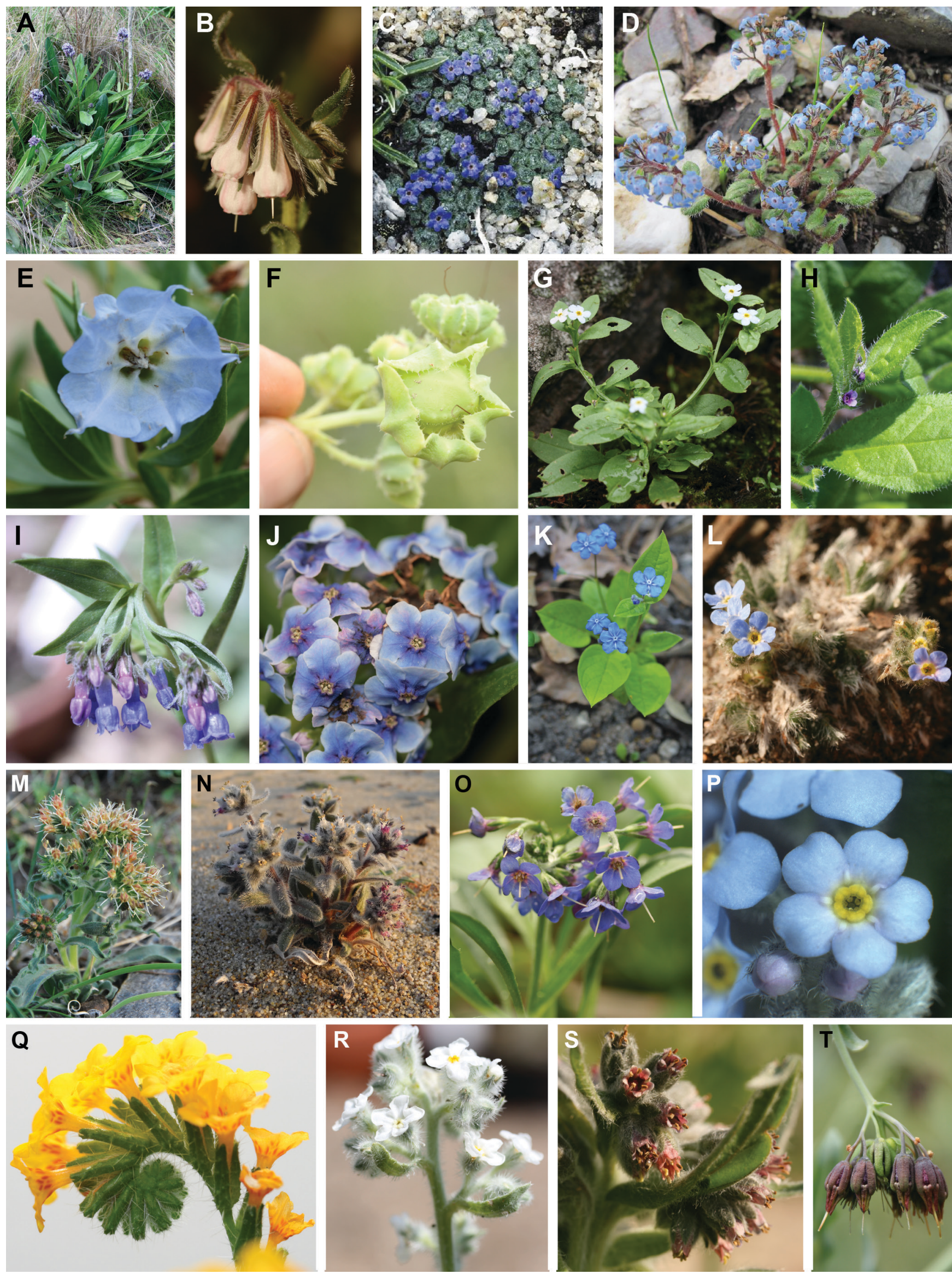
Caccinia (Trichodesmeae), share a particular type of tricolporate pollen that is uncommon in the Cynoglosseae (Avetisjan, 1956; Weigend \& al., 2016).

Thyrocarpus, with three species restricted to China and Vietnam (Zhu \& al., 1995) also remains unplaced. In the original description by Hance (1862) a close relationship with Bothriospermum Bunge was suggested as these two genera differ only in details of nutlet morphology. Johnston (1924) pointed to a close relationship between them due to their similar habit and flower structure, differing only in the direction and the development of the nutlet margin.

The monospecific Brachybotrys Maxim. ex Oliv., Chionocharis I.M.Johnst., and Trigonocaryum Trautv. are among the problematic taxa that have already been analyzed with molecular data, and have been retrieved as members of the Cynoglosseae (Cohen, 2014). However, their placement was poorly supported in these trees. Brachybotrys paridiformis Maxim. ex Oliv. occurs in northeast Asia and consists of mesophytic rhizomatous forest herbs that have a characteristic widely campanulate corolla with a porrect limb (Weigend \& al., 2016). Popov (1953: 237) included the genus in the subtribe Trigonotidinae together with Trigonotis, Cerinthe L. and Mertensia, and asserted that Brachybotrys is related with the latter on the basis of similarities in the stamens. However, character polarity is disregarded in this discussion and these conclusions are therefore dubious. Previous phylogenetic studies have already shown that Cerinthe and Mertensia belong in two separate clades of Boraginaceae (Lithospermeae and Cynoglosseae, respectively; Nazaire \& Hufford, 2012; Weigend \& al., 2013). On the other hand, Chionocharis hookeri (C.B.Clarke) I.M.Johnst. is a highly distinctive species of high alpine cushion-forming plants (3500-5800 m) distributed from northeast India to China (Zhu \& al., 1995; Luo \& al., 2016). Johnston (1924) suggested a close relationship with the Himalayan Lasiocaryum I.M.Johnst. as both are distributed in the same geographical region and are characterized by similar strigose nutlets, pubescent stigmas and broad leaves. In the phylogenetic study by Weigend \& al. (2013) Lasiocaryum was recovered as the sister genus to Microcaryum I.M. Johnst., another high-mountain Himalayan genus, and both of them were retrieved with Trichodesmeae. Finally, the Caucasian Trigonocaryum, whose type was initially described as Myosotis involucrata Steven, was originally included in the tribe Boragineae (as Anchuseae W.D.J.Koch) owing to the flowers with contorted corolla lobes like those of Anchusa L., and was treated in a separate monospecific genus (see Johnston, 1924). Later on, Kerimov \& Askerova (2005) placed it in its own tribe (Trigonocaryeae Kerimov), segregated because of the presence of blue-violet flowers, flat gynobase, basal oval cicatrix and seeds with a caruncle. However, these characters as well as many others associated with the reproductive and vegetative organs are also observed in Myosotis L. (Popov, 1953), and therefore Trigonocaryum involucratum (Steven) Medw. is now commonly accepted as a member of that genus, as originally described.

The recognition of natural subfamilies and tribes in the Boraginaceae has been challenged by the above genera whose classification has been obscured by their intriguing morphology. Our aims are to re-evaluate the traditional infrafamilial subdivisions of Boraginaceae and the monophyly of the main lineages of Cynoglosseae s.l. retrieved in the study by Weigend \& al. (2013), to elucidate the phylogenetic relationships of the problematic genera Afrotysonia, Anoplocaryum, Craniospermum, and Thyrocarpus, and to confirm the placement of the monospecific genera Brachybotrys, Chionocharis, and Trigonocaryum. In order to address these topics, a phylogenetic analysis based on maximum likelihood and Bayesian

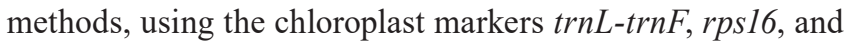
$\operatorname{trn} S-G$, and the internal transcribed spacer of nuclear ribosomal DNA (ITS), was performed. These markers have been used successfully to study the phylogeny and evolution of the Boraginales (Mansion \& al., 2009; Weigend \& al., 2009, 2013, 2014; Luebert \& al., 2011; Gottschling \& al., 2014) and therefore are suitable markers to address the goals of this study.

\section{MATERIALS AND METHODS}

Taxon sampling. - We sequenced 174 species of the Boraginales including 4 outgroup and 170 ingroup species from 73 of ca. 90 genera of Boraginaceae. Our study includes a subset of the taxa analyzed by Weigend \& al. (2013), which has been enlarged to include representatives of Afrotysonia (one of three species: A. glochidiata R.R.Mill), Anoplocaryum (two of five species: A. compressum (Turcz.) Ledeb. and A. helenae Volot.), Craniospermum (four of six species: C. echioides (Schrenk) Bunge, C. mongolicum I.M.Johnst., C. subvillosum Lehm., C. tuvinicum Ovczinnikova, plus an unidentified species), Thyrocarpus (one of three species: T. sampsonii Hance), and the sole species of the monospecific genera Brachybotrys (B. paridiformis), Chionocharis (C. hookeri), and Trigonocaryum (T. involucratum). Circumscription of genera and tribes follows the taxonomic treatment by Weigend \& al. (2016). Nomenclature of the major Boraginaceae clades is according to Weigend \& al. (2013).

Most of the samples used in this study are part of a DNAbank maintained at the Nees-Institut for Plant Biodiversity at the University of Bonn. This collection contains more than 1400 fully documented DNA accessions of Boraginales, which have been isolated from specimens collected by the authors during numerous field trips or that have been obtained from herbarium loans, botanical gardens and colleagues. Additional DNA samples have been extracted from silica gel-dried material provided by the collaborators named in the Acknowledgements. All sampled plant material with its geographic origin, herbarium voucher specimen, and GenBank accession numbers is listed in (Appendix 1).

DNA sequencing and phylogenetic analyses. - Total genomic DNA was extracted from ca. $20 \mathrm{mg}$ of dried leaf tissue following a modified version of the $2 \times$ CTAB method of Doyle \& Doyle (1987), with a final precipitation step in isopropanol at $-20^{\circ} \mathrm{C}$ overnight. The resulting DNA was visualized in $1 \%$ agarose gels using GelStar Nucleic Acid Stain (Lonza Rockland, Rockland, Maine, U.S.A.), and its quality and concentration was measured in a NanoDrop 2000 spectrophotometer 
(Thermo Fisher Scientific, Waltham, Massachusetts, U.S.A.). In some cases an additional purification using polyethylene glycol was necessary due to the high concentration of secondary compounds in the samples.

The chloroplast (cp) DNA regions tRNA-Leu $(\operatorname{trn} L)$ gene and $\operatorname{trn} L-\operatorname{trn} F$ intergenic spacer (here referred to as $\operatorname{trn} L-F$ ), $r p s 16$, and $\operatorname{trnS}-G$ as well as the nuclear ribosomal DNA internal transcribed spacer (ITS) were amplified and sequenced. We used the same universal primers and standard protocols as described in Weigend \& al. $(2009,2013)$ and Gottschling \& al. (2014). These studies have shown that the selected markers are suitable for studying the phylogenetics of the Boraginales at different taxonomic levels. We used Geneious v.8.1.2 (http:// www.geneious.com, Kearse \& al., 2012) to concatenate and align the resulting sequences, using the multiple-global alignment option with free end gaps, progressive pairwise algorithm with a cost matrix of $65 \%$ similarity (matchCost $=5.0$ and mismatchCost $=-4.0$ ), gap open penalty $=12$, and gap extension penalty $=3$, which are the settings recommended in the manual for multiple related DNA sequences that differ in length. Phylogenetic tree reconstruction under maximum likelihood (ML) was conducted in the programs RAxML v.8.0.0 (Stamatakis, 2014) and raxmlGUI v.1.0 (Silvestro \& Michalak, 2012) using the "per-partition branch length" option. Statistical support for nodes was assessed with 1000 ML bootstrap replicates. Bayesian posterior probabilities were estimated with the Markov chain Monte Carlo (MCMC) method implemented in MrBayes v.3.2.4 (Huelsenbeck \& Ronquist, 2001; Ronquist $\&$ al., 2012), using six parallel runs each with four chains and 4 million generations, with parameters sampled every 1000 generations. The ML and Bayesian analyses were run under the GTR $+\mathrm{G}$ substitution model, which was identified as the bestfitting model for each cpDNA partition by the Akaike information criterion in FindModel (available at: http://www.hiv.lanl. gov/content/sequence/findmodel/findmodel.html). These data partitions were first analyzed separately, and in the absence of statistically supported topological conflict (defined as $>80 \%$ bootstrap support) were combined following Wiens (1998). The African genera Wellstedia Balf.f. and Codon L. were used as outgroups following Weigend \& al. (2010, 2013).

\section{RESULTS}

The chloroplast markers chosen for this study were successfully sequenced for $99 \%$ of the taxa, meaning that almost no missing data is found in our alignment. We were unable to amplify either trnS- $G$ or $t r n L-F$ for Andersonglossum occidentale (A.Gray) J.I.Cohen and Decalepidanthus elongatus (Decne.) Dickoré \& Hilger (see Appendix 1) because in these samples the final DNA concentration was very low $(<20 \mathrm{ng} / \mu \mathrm{l})$. The combined matrix of the chloroplast datasets contained 4306 aligned nucleotides (trnL-F: 1-1287; rps 16: 1288-2483; trnS-G: 2484-4306). Multiple sequence alignments of the chloroplast markers are provided as supplementary data. The ITS region was amplified for all samples except for Decalepidanthus trollii (Melch.) Dickoré \& Hilger. In the ITS alignment
(967 aligned nucleotides), while the 5.8S rRNA is totally conserved among species, the ITS1 and ITS2 regions are extremely variable and largely impossible to align meaningfully (data available upon request). The backbone of the resulting ML and Bayesian trees is very poorly resolved and not supported (i.e., ML bootstrap $<80 \%$ and posterior probability $<0.95$; see ITS tree in Electr. Suppl.: Fig. S1). Essentially, the problem seems to be concentrated in the Core-Cynoglosseae, which is retrieved as an unresolved basal polytomy. However, the monophyly of Boraginaceae is supported and the bulk of the tribes and subtribes here recognized are retrieved as monophyletic, if usually on an unresolved backbone (Electr. Suppl.: Fig. S1). We therefore suspect that different paralogues have been sequenced, but a solution for this is beyond the scopes of our study. For this reason only the results obtained with the chloroplast dataset will be discussed in detail, and those obtained with ITS data will only be discussed in passing where relevant.

The partitioned analysis showed no incongruence among the chloroplast regions analyzed, meaning that no conflicting well-supported clades were obtained in the single-gene trees. The resulting tree from the ML and Bayesian analyses were completely compatible and both retrieved a well-resolved topology, with most nodes of the backbone receiving $100 \%$ ML bootstrap (ML-BS) and posterior probability (PP) of 1.0, as indicated with the black boxes in Fig. 2. The phylogeny shows Echiochilon Desf. and Antiphytum DC. ex Meisn. (Echiochileae) as the sister clade to the remaining Boraginaceae (Fig. 3). All these species are grouped in two well-supported branches, namely the Boragineae + Lithospermeae (ML-BS $=87 \%, \mathrm{PP}=1.0$; Fig. 3 ) and the Cynoglosseae s.l. (ML-BS $=100 \%, \mathrm{PP}=1.0$; Fig. 4). In the Cynoglosseae s.l. most clades along the backbone are well supported. In this group the Trichodesmeae (Caccinia + Trichodesma; ML-BS = 96\%, PP = 1.0; Fig. 4; Electr. Suppl.: Fig. S1) are sister to the Lasiocaryum-clade (Chionocharis hookeri and Lasiocaryum + Microcaryum; ML-BS $=100 \%$, $\mathrm{PP}=1.0$; Fig. 4; Electr. Suppl.: Fig. S1).

The remaining Cynoglosseae s.l. are grouped in a wellsupported clade (ML-BS $=99 \%$; $\mathrm{PP}=1.0$; Fig. 4), which is divided into two lineages. In the first lineage, the Mertensiaclade (crown node support: ML-BS $=91 \%, P P=1.0$; Fig. 4; ML-BS $=93 \%$, PP $=1.0$; Electr. Suppl.: Fig. S1) is sister to the Omphalodes-clade (crown node support: ML-BS $=100 \%$, PP =1.0; Fig. 4; Electr. Suppl.: Fig. S1), and these together form the sister group of the Eritrichieae s.str. (crown node support, $\mathrm{ML}-\mathrm{BS}=99 \%$, $\mathrm{PP}=1.0$; Fig. 4 ; $\mathrm{ML}-\mathrm{BS}=93 \%, \mathrm{PP}=1.0$; Electr. Suppl.: Fig. S1), albeit without support. Asperugo procumbens L. and Memoremea scorpioides (Haenke) A.Otero \& al. are retrieved as successive sister lineages of the Mertensiaclade, in which Anoplocaryum is retrieved as sister to Mertensia species (ML-BS $=100 \%, \mathrm{PP}=1.0$; Fig. 4; $\mathrm{ML}-\mathrm{BS}=84 \%$, $\mathrm{PP}=1.0$, Electr. Suppl.: Fig. S1). In the second lineage of Cynoglosseae s.l. (Fig. 5), the species of Craniospermum are monophyletic (crown node support: ML-BS $=100 \%, \mathrm{PP}=1.0$; Fig. 5; Electr. Suppl.: Fig. S1) and are sister to the Myosotideae (crown node support: $\mathrm{ML}-\mathrm{BS}=97 \%$, PP $=1.0$; Fig. 5; ML-BS $=98 \%$, $\mathrm{PP}=1.0$; Electr. Suppl.: Fig. S1) and the Core-Cynoglosseae. In the Myosotideae the monospecific Brachybotrys is sister to 


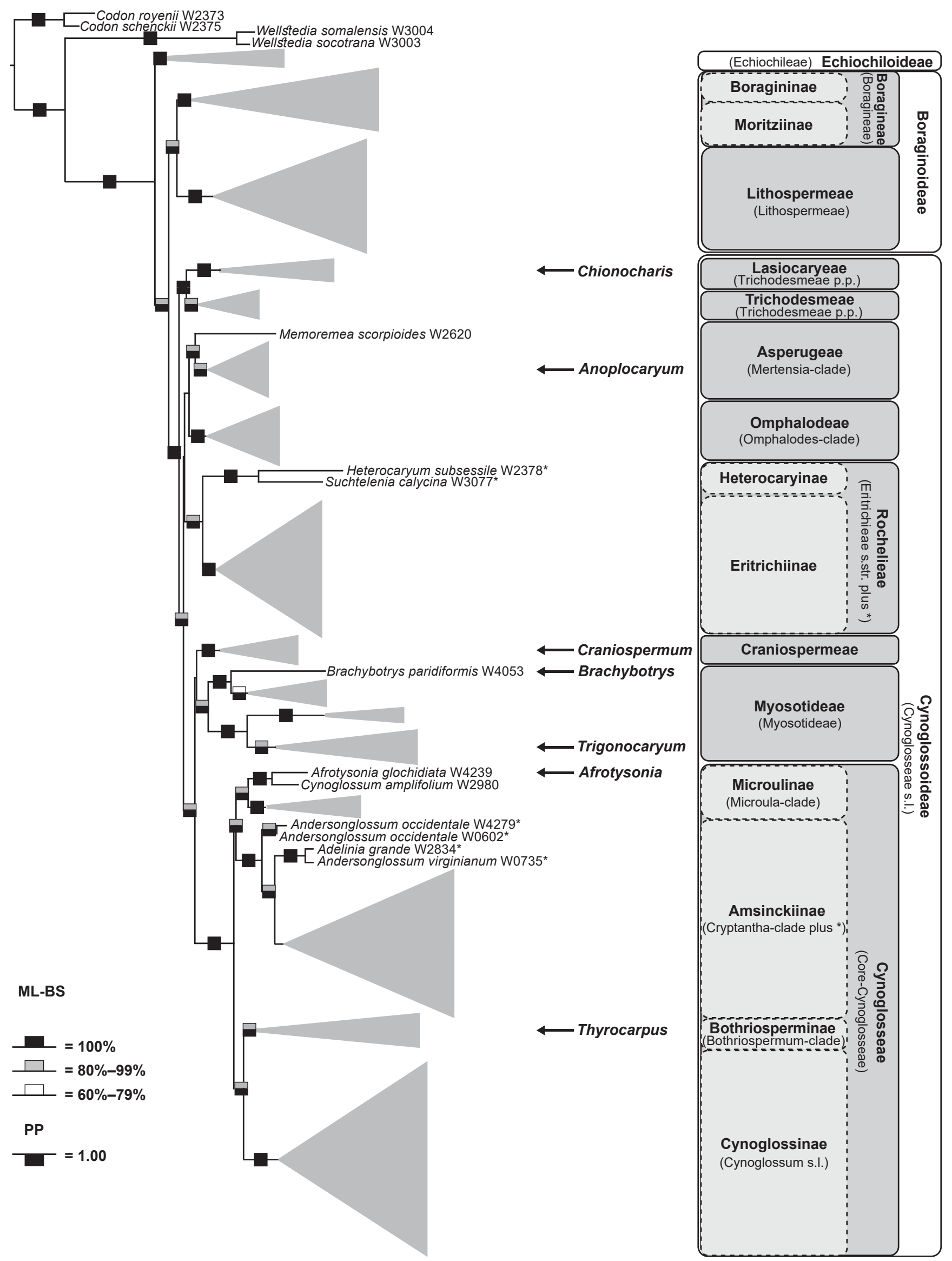


the clade of Trigonotis species (ML-BS $=100 \%, \mathrm{PP}=1.0$; Fig. 5; $\mathrm{ML}-\mathrm{BS}=98 \%$, PP = 1.0; Electr. Suppl.: Fig. S1), and these two genera together are sister to a clade consisting of Decalepidanthus + Myosotis (ML-BS $=100 \%, \mathrm{PP}=1.0$; Fig. 5; ML-BS $=88 \%$, PP $=1.0$; Electr. Suppl.: Fig. S1), with Trigonocaryum involucratum embedded within.

The Core-Cynoglosseae is very well supported in the $\mathrm{cp}$ trees (ML-BS $=100 \%$, PP = 1.0; see Fig. 5) and splits into two main lineages, but remains entirely unresolved in the ITS tree (Electr. Suppl.: Fig. S1). In the first lineage Afrotysonia glochidiata + Cynoglossum amplifolium Hochst. ex A.DC. $(\mathrm{ML}-\mathrm{BS}=100 \%, \mathrm{PP}=1.0)$ form the sister clade of the Asian Microula Benth. species, in which Metaeritrichium microuloides W.T.Wang and Actinocarya tibetica Benth. are embedded (Microula-clade, ML-BS $=100 \%, \mathrm{PP}=1.0$ ). This first lineage is sister to a clade in which two accessions of the North American Andersonglossum occidentale are at the base of a grade that includes other North and South American species, namely Andersonglossum virginianum (L.) J.I.Cohen, Adelinia grande (Douglas ex Lehm.) J.I.Cohen, Harpagonella palmeri A.Gray, Pectocarya DC. ex Meisn. spp., Dasynotus daubenmirei I.M.Johnst., Cryptantha Lehm. ex G.Don s.l. spp., Plagiobothrys Fisch. \& C.A.Mey. spp., and Amsinckia Lehm. spp. Adelinia, Amsinckia, Andersonglossum, Cryptantha s.1., Dasynotus, Harpagonella, Pectocarya, and Plagiobothrys together constitute the Cryptantha-clade (crown node support: ML-BS $=100 \%, \mathrm{PP}=1.0)$. The second lineage of the CoreCynoglossae consists of two sister clades (ML-BS $=95 \%$, PP $=1.0)$. One of these, referred to as the Bothriospermum-clade (Fig. 5), includes Bothriospermum spp. together with Thyrocarpus sampsonii, Nihon japonicum (Thunb.) A.Otero \& al., and $N$. akiensis (Kadota) A.Otero \& al. (ML-BS $=96 \%$, PP

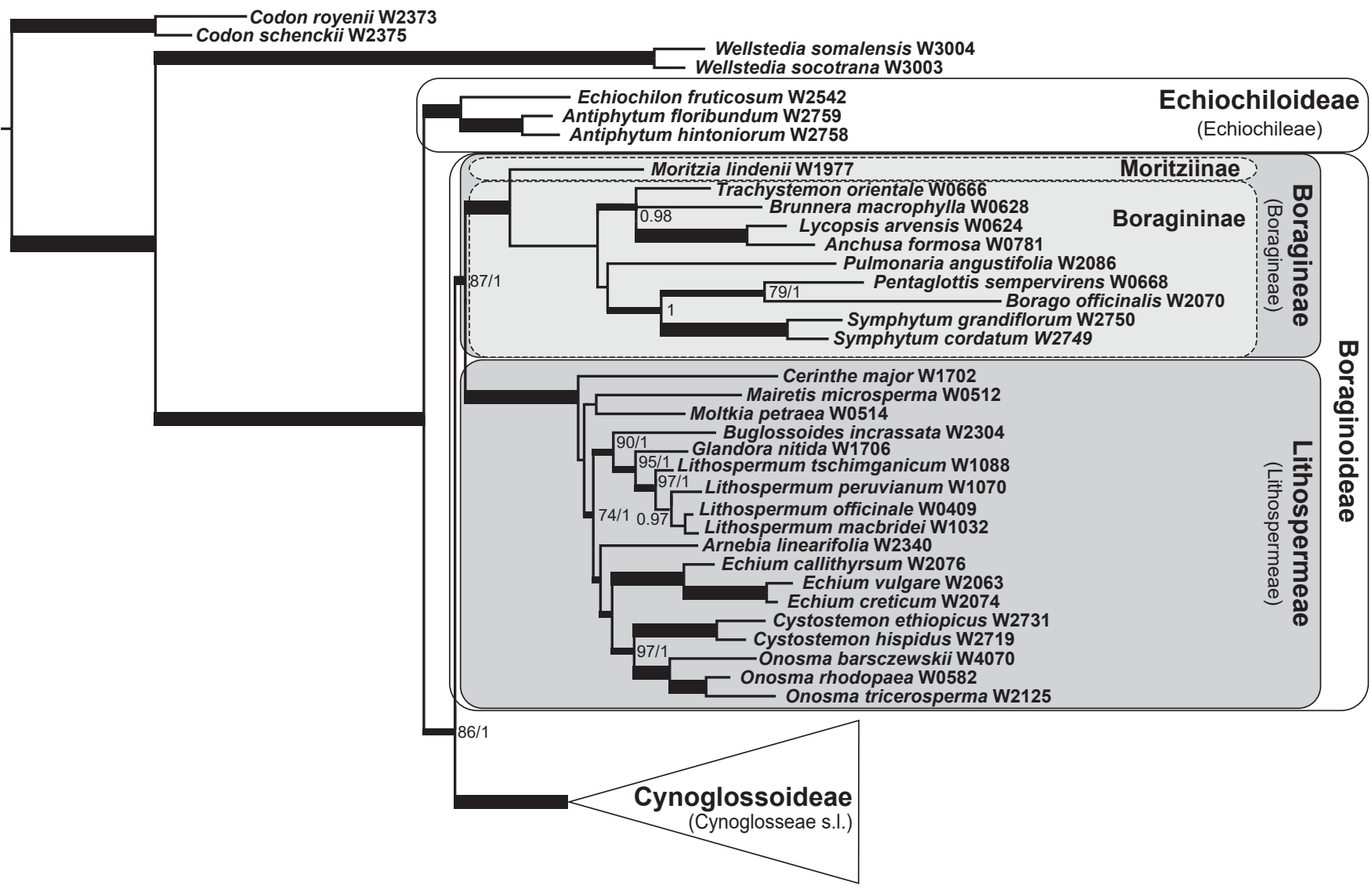

$\Delta$ Fig. 3. Details of the ML tree of Boraginaceae showing the phylogenetic relationships of the subfamilies Echiochiloideae and Boraginoideae. Branch thickness is proportional to the statistical support of clades, with the thickest branches indicating maximum support (ML-BS $=100 \%, \mathrm{PP}=1.0)$. Other support values are shown next to the corresponding node (ML-BS / PP). The clades are labeled according to the new infrafamilial classification (bold face); the clade names used by Weigend \& al. (2013) are in parentheses. Species names are followed by the corresponding internal DNA number.

Fig. 2. Simplified maximum likelihood tree of Boraginaceae based on the analysis of 4306 nucleotides and 170 ingroup species, with Wellstedia and Codon as outgroups. Statistical support for nodes is indicated with boxes on each branch according to the values described in the inset (ML-BS: maximum likelihood bootstrap, PP: posterior probability). The position of previously unplaced genera is indicated by arrows in front of the corresponding clade. The main clades of Boraginaceae are labeled according to the new infrafamilial classification (bold face). The clade names used in Weigend \& al. (2013) are written in parentheses; the species that were originally not circumscribed in those clades are marked with an asterisk. Species names are followed by the corresponding internal DNA number. 
=1.0). The second clade consists of the remainder of Cynoglosseae (Cynoglossum s.1.), which contains the majority of Cynoglossum species together with Lindelofia, Mattiastrum, Microparacaryum (Popov ex Riedl) Hilger \& Podlech, Paracaryum, Paracynoglossum, Pardoglossum Barbier \& Mathez, Rindera, Solenanthus, and Trachelanthus (crown node support of Cynoglossum s.1.: ML-BS $=100 \%, \mathrm{PP}=1.0$ ). In the CoreCynoglosseae only the sampled species of Amsinckia, Dasynotus, Nihon, Pectocarya, and Plagiobothrys, are monophyletic in these analyses (Fig. 5), which is likely due to limited sampling in the case of Plagiobothrys (Hasenstab-Lehman \& Simpson 2012; Guilliams, 2015).

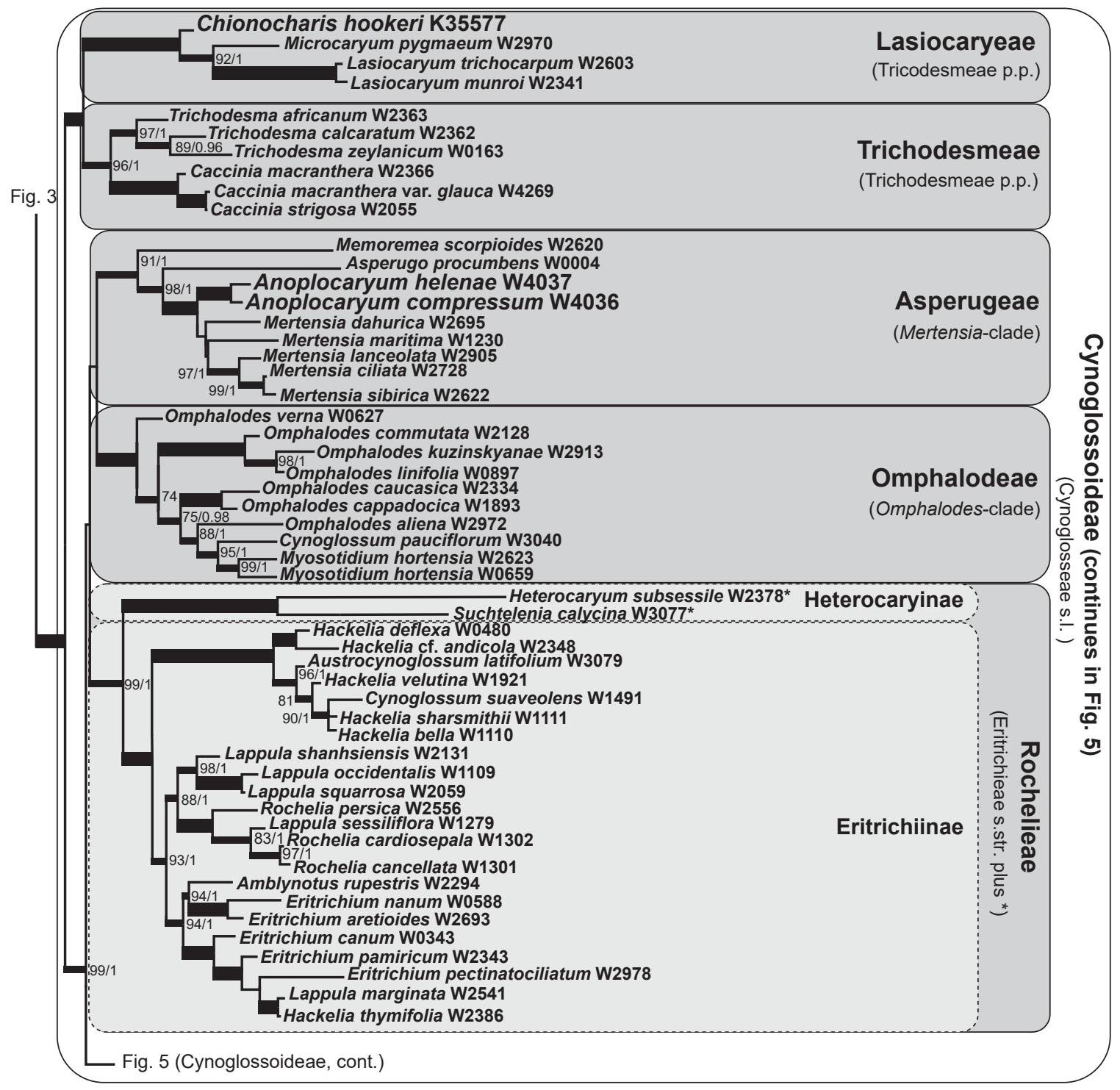

Fig. 4. Details of the ML tree of Boraginaceae showing the phylogenetic relationships of the Cynoglossoideae, particularly the Lasiocaryeae, Trichodesmeae, Asperugeae, Omphalodeae, and Rochelieae. The problematic genera are highlighted with a bigger font-size. Branch thickness is proportional to the statistical support of clades, with the thickest branches indicating maximum support (ML-BS $=100 \%, \mathrm{PP}=1.0)$. Other support values are shown next to the corresponding node (ML-BS / PP). The clades are labeled according to the new infrafamilial classification (bold face). The clade names used by Weigend \& al. (2013) are written in parentheses; the species that were originally not circumscribed in those clades are marked with an asterisk (Trichodesmeae p.p. = Trichodesmeae pro parte). Species names are followed by the corresponding internal DNA number.

Fig. 5. Details of the ML tree of Boraginaceae showing the phylogenetic relationships of the Cynoglossoideae, particularly the Craniospermeae, the Myosotideae, and the Cynoglosseae. The problematic genera are highlighted with a bigger font-size. Branch thickness is proportional to the statistical support of clades, with the thickest branches indicating maximum support (ML-BS $=100 \%, \mathrm{PP}=1.0)$. Other support values are shown next to the corresponding node (ML-BS / PP). The clades are labeled according to the new infrafamilial classification (bold face). The clade names used by Weigend \& al. (2013) are written in parentheses; the species that were originally not circumscribed in those clades are marked with an asterisk. Species names are followed by the corresponding internal DNA number. 


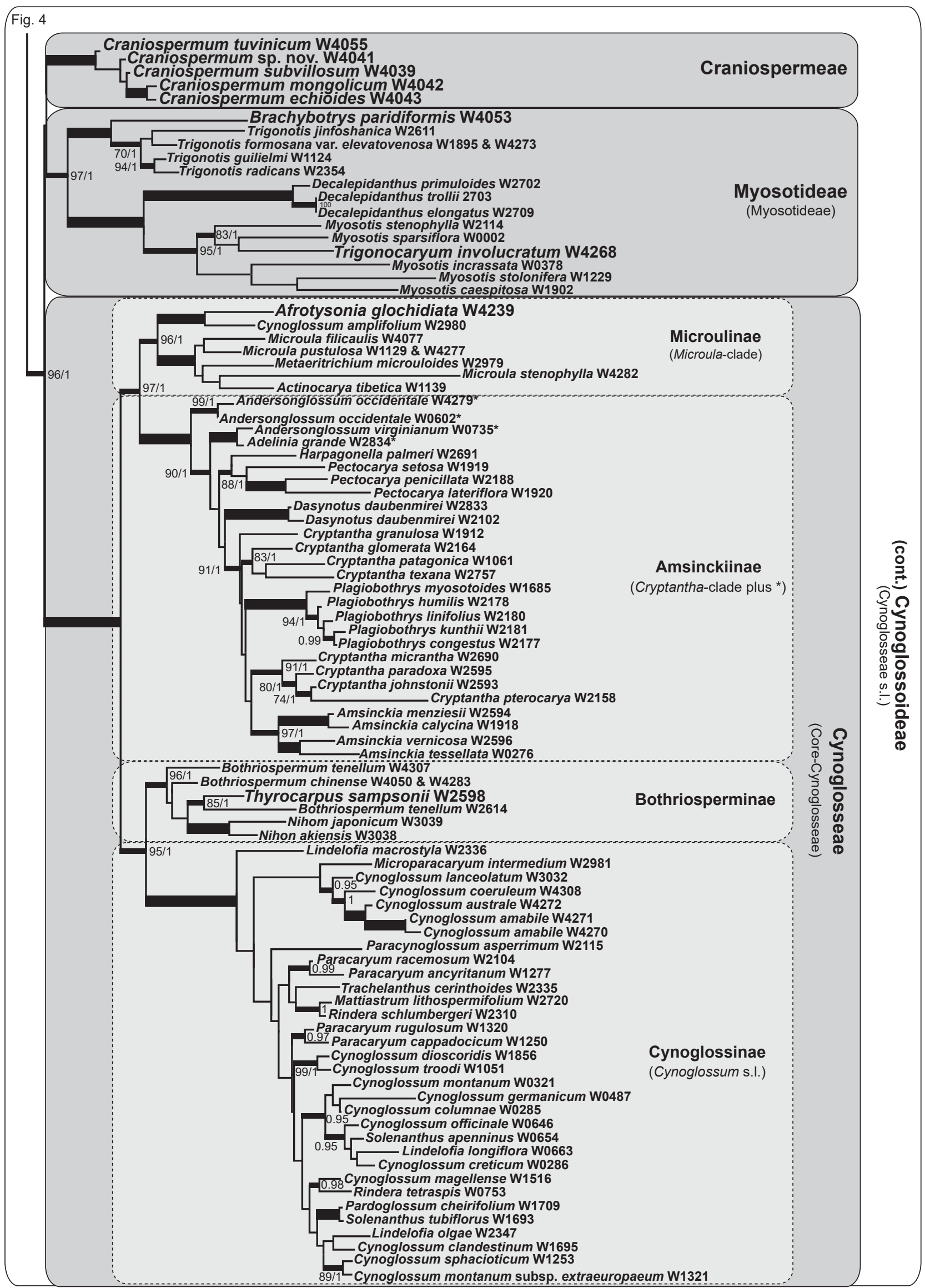




\section{DISCUSSION}

Major clades of Boraginaceae. - The molecular phylogeny presented in this study (Fig. 2) provides very good resolution and support for the main clades of Boraginaceae, and the uncertainties about the placement of the problematic genera presented in the introduction can be satisfactorily addressed. Echiochileae is confirmed as the sister clade to the remaining species of Boraginaceae, with Lithospermeae + Boragineae (Fig. 3) sister to Cynoglosseae s.l. (Figs. 2-5). Although this basic topology is the same as in Weigend \& al. (2013), the backbone of the Cynoglosseae s.l. as well as most internal nodes are now better resolved and supported, indicating that the combined analysis of the cpDNA regions $\operatorname{rps} 16, \operatorname{trn} L-F$, and $\operatorname{trn} S-G$ plus the newly sequenced taxa significantly improved the overall results.

The well-supported placement of the Trichodesmeae and the Lasiocaryum-clade as sister to the remaining Cynoglosseae s.l. is congruent with the results of Weigend \& al. (2013; Figs. 2,4). The monospecific Chionocharis is resolved as the sister taxon to Microcaryum +Lasiocaryum (Lasiocaryum-clade; Fig. 4). This high-mountain Himalayan clade is a natural group of small, annual to perennial herbs, whose main synapomorphy is the presence of a turbinate, mostly pubescent nutlet (Weigend \& al., 2016; see Fig. 1C, D). The Trichodesmeae (Fig. 4; see also Fig. 1E, F) consists of robust herbs or shrubs ranging from Africa to central southern Asia and Australia, which are characterized by very short corolla tubes and mostly spreading corolla lobes with long exserted anthers. According to Weigend \& al. (2013) the Trichodesmeae in an expanded definition (i.e., including the Lasiocaryum-clade) could only be morphologically defined by the broad attachment of the nutlets to the gynobase, since this is the only character shared between these two clades (Johnston, 1924; Zhu \& al., 1995), which otherwise represent morphologically highly divergent groups.

A very interesting finding is that Anoplocaryum is retrieved in the Mertensia-clade with maximum support (Figs. 2, 4). Johnston (1924) and Weigend \& al. (2016) pointed to a close relationship between Mertensia and Anoplocaryum as members of their Mertensia-clade. The authors argued that these north temperate genera are differentiated from all other taxa by the presence of nutlets with an irregularly ovoid shape, sometimes indistinctly winged, and attached to the gynobase with a short stipe that arises from the adaxial side (Weigend \& al., 2016). In the studies by Nazaire \& Hufford (2012) and Weigend \& al. (2013), in which Anoplocaryum was not included, Mertensia is sister to the monospecific Asperugo. In the present study Asperugo is placed as sister to a Mertensia + Anoplocaryum clade, with Memoremea scorpioides sister to these (Fig. 4). Asperugo procumbens has been treated in its own monospecific tribe Asperugeae (e.g., Ovchinnikova, 2007, 2009 ) and is considered an aberrant genus of annual weeds, with a unique habit, an anomalous calyx morphology, and a distinctive arrangement and development of the nutlets (Popov, 1953; Hilger, 2014; Weigend \& al., 2016; see Fig. 1H). Memoremea scorpioides is also morphologically distinct compared to species of Omphalodes (where it has been placed for a long time as $O$. scorpioides (Haenke) Schrank), and has scorpioid cymes subtended by bracts, strongly curved embryos, and opposite lower leaves, which are atypical characters in the Cynoglosseae (Brand, 1921). These apomorphies led Johnston (1924) to conclude that $O$. scorpioides might be segregated in its own genus and hence Otero \& al. (2014) described the monospecific Memoremea, distinguished by the apical attachment scar, the incurved nutlet with an air chamber, and the presence of trichomes on the nutlet. However, Omphalodes s.str. still remains paraphyletic, even after these re-alignments.

The position of the newly sequenced species of Craniospermum in a well-supported clade within the Cynoglosseae s.l. (Figs. 2, 5) is congruent with previous taxonomic classifications that treat it as the sole member of the tribe Craniospermeae (Popov, 1953; Ovchinnikova, 2009). The genus has traditionally been recognized as a clearly defined group (e.g., Bentham, 1876; Johnston, 1924), differentiated by the presence of a corolla throat without faucal appendages, exserted stamens, and nutlets with an abaxial cupular emergence (Fig. 6; Weigend $\&$ al., 2016). The hypothesis of an evolutionary relationship between Craniospermum and Trichodesma (Ovchinnikova, 2009) is at odds with our data, which show the Trichodesmeae embedded in a relatively distant lineage of the Cynoglosseae s.l. (Fig. 2). Therefore, the similarities in pollen and fruit morphology observed by Ovchinnikova (Ovchinnikova, 2001) are not indicative of evolutionary relationship in this case, these features constituting symplesiomorphies or the products of convergent evolution.

The Craniospermeae form a clade with the Myosotideae, although with low support, and both are sister to an expanded Core-Cynoglosseae (Fig. 5). The Myosotideae include the newly sequenced genera Brachybotrys and Trigonocaryum, the former sister to Trigonotis and the latter deeply embedded within Myosotis (Fig. 5). The sister-group relationship between Trigonotis and Brachybotrys contradicts the hypothesis by Popov (1953), who suggested close affinities with Mertensia. Furthermore, these three genera were placed in the Trigonotideae (Popov, 1953; Riedl, 1997), although Riedl (1968) did not include Brachybotrys in his original description of the tribe. Nonetheless, recent phylogenetic studies have already shown that Trigonotideae is not monophyletic (Weigend \& al., 2010; 2013). A close relationship between Trigonotis and Myosotis in two sister clades of an expanded Myosotideae was already discussed by Weigend \& al. (2013). The placement of Trigonocaryum involucratum is in agreement with its synonymization as Myosotis involucrata (see Weigend \& al., 2016). Our molecular tree provides high support and good resolution for an expanded Myosotideae (Figs. 2, 5), which includes Brachybotrys, Trigonotis, and Myosotis. This clade, together with Decalepidanthus (= Pseudomertensia; see Dickoré \& Hilger, 2015), is referred to as the Myosotis-group in Weigend $\&$ al. (2016; see Fig. 1O, P), and consists of small-flowered herbs with soft, often appressed pubescence and small, lentil-shaped to dorsally keeled or obliquely tetrahedral, smooth and dark brown to black nutlets.

The remaining Boraginaceae constitute our Core Cynoglosseae (Figs. 2, 5; Weigend \& al., 2013) and are divided into 
two sister clades. In the first clade, the position of Afrotysonia glochidiata together with Cynoglossum amplifolium is a novel element that raises interesting morphological and biogeographic questions, as both African species are recovered as sister to the Asian Microula-clade. The latter includes Metaeritrichium
W.T.Wang and Actinocarya Benth., which have recently been synonymized with Microula (Weigend \& al., 2016), making the latter monophyletic according to the topology of our molecular tree. The relationship between Afrotysonia and Microula is challenging as they have never been associated and their
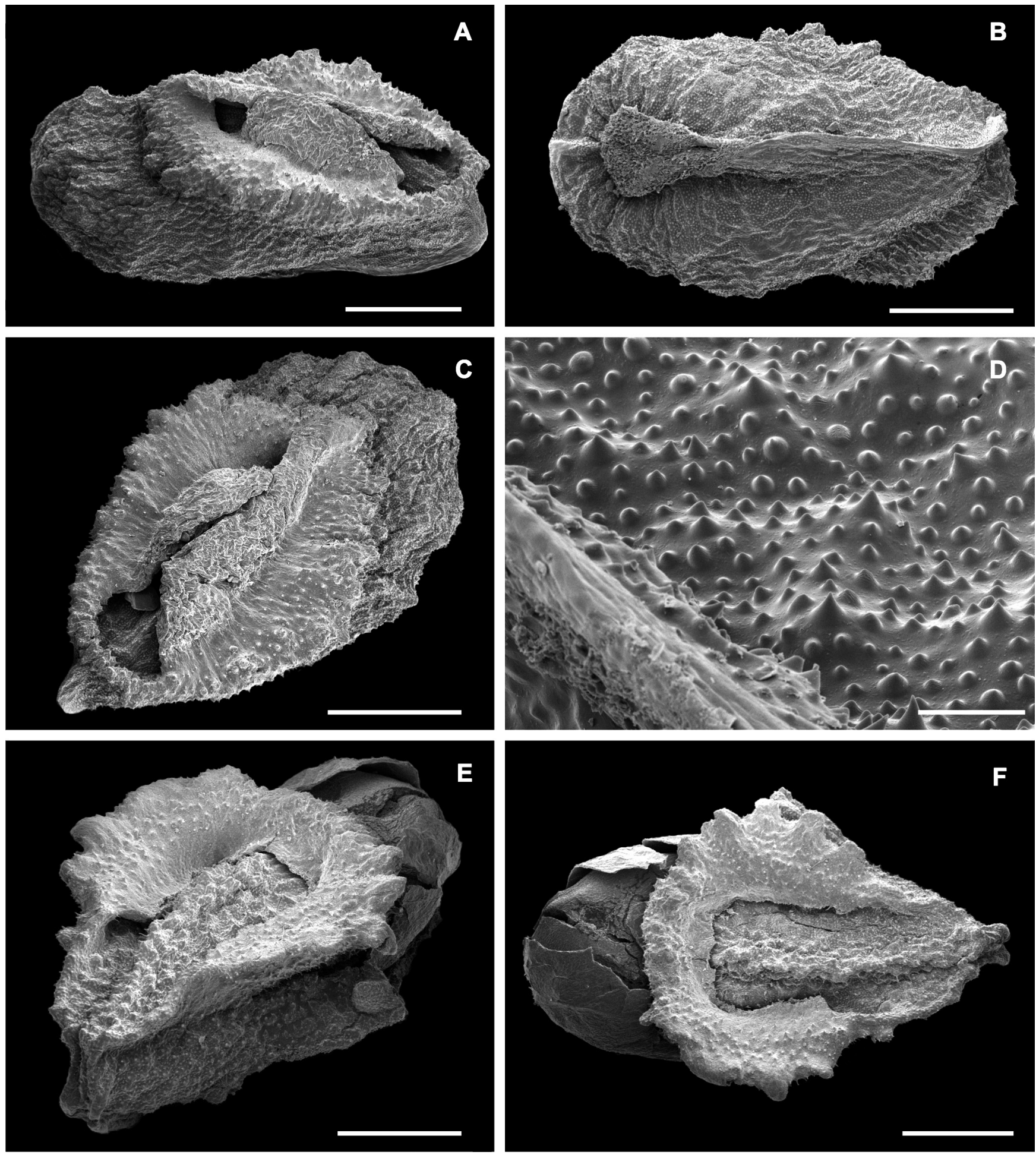

Fig. 6. Nutlet morphology in Craniospermum. Scanning electron micrographs of two Mongolian species. A-D, Craniospermum canescens DC., W. Hilbig, D. Bumschaa \& al. 104/79 (HAL); E \& F, C. mongolicum I.M.Johnst., E. Jäger F225 (HAL). A, Lateral view; B, Dorsal view; C, E \& F, Ventral view showing the attachment scar; D, detail of nutlet surface. — Scale bar equals $800 \mu \mathrm{m}$ in A-C, E \& F; $60 \mu \mathrm{m}$ in D. 
geographic ranges do not overlap. Morphologically, the two genera have similar leaves (basal and cauline), flowers with pedicels often elongating in fruit, and crescent-shaped faucal scales (but also depressedly rectangular in Microula; Weigend $\&$ al., 2016). None of these, however, are unique or likely to be synapomorphic characters. Nevertheless, only one of three species of Afrotysonia is included in this study, and therefore the monophyly and relationships of the genus remain elusive. Cohen (2014) resolved Afrotysonia as a member of Heliotropiaceae, a result that would imply a radical morphological re-definition of the latter family. Since the morphology of Afrotysonia clearly falls within the typical circumscription of Boraginaceae, we regard the placement by Cohen (2014) as spurious. The Afrotysonia-Microula clade is sister to the Cryptantha-clade, within which the North American Andersonglossum and Adelinia (Cohen, 2015) are now resolved in a basal grade. Interestingly, Andersonglossum is clearly retrieved as polyphyletic, whereas there is no support for the relevant clades in Cohen (2015). The Cryptantha-clade comprises several North and South American genera (Amsinckia, Cryptantha s.l. sensu Hasenstab-Lehman \& Simpson, 2012, or Cryptantha sensu Johnston, 1925, 1927, Dasynotus, Harpagonella, Pectocarya, and Plagiobothrys). In this latter clade, Amsinckia and Plagiobothrys are monophyletic and embedded in Cryptantha s.l. (Fig. 5). The non-monophyly of Cryptantha has been reported in several studies (Hasenstab-Lehman \& Simpson, 2012; Weigend \& al., 2013; Ripma \& al., 2014). On the basis of a phylogenetic analysis of the Cryptantha-clade that included 64 taxa from all recognized sections in Cryptantha s.l. and other recognized genera in the group (except Harpagonella), Hasenstab-Lehman \& Simpson (2012) proposed a subdivision of Cryptantha s.l. into several segregate genera. This proposal is not addressed in detail here and is the subject of ongoing work. Plagiobothrys was also shown to be non-monophyletic in their study, a finding corroborated by ongoing molecular phylogenetic studies of the genus (M. Guilliams, unpub. data).

In the second lineage of the Core-Cynoglosseae Thyrocarpus is embedded in a clade with two species of Nihon together with Bothriospermum chinense Bunge and B. tenellum (Hornem.) Fisch. \& C.A.Mey., which makes Bothriospermum paraphyletic. The close relationship between Bothriospermum and Thyrocarpus was expected, as Thyrocarpus has been considered a close relative of Bothriospermum since its description (e.g., Hance, 1862; Johnston, 1924; Zhu \& al., 1995; Weigend $\&$ al., 2016). Our results agree with Otero \& al. (2014), who found another species of Bothriospermum (i.e., B. secundum Maxim.; B. chinense and B. tenellum were not included in that study) as sister to Thyrocarpus sampsonii. Thyrocarpus is likely also closely allied to Antiotrema Hand.-Mazz., which together with Bothriospermum has nutlets with a two-layered wing, a unique character that has only been observed in these three genera (Johnston, 1924; Weigend \& al., 2016). A close relationship with Nihon akiensis and $N$. japonicum (formerly in Omphalodes), which in our tree are deeply embedded in the Bothriospermum-clade (Fig. 5), also fits with the results of Otero \& al. (2014), where Bothriospermum and Thyrocarpus form a clade with the same Nihon species. However, neither
Antiotrema nor the remaining species of Bothriospermum and Thyrocarpus have been included either here or in Otero \& al. (2014), and thus detailed phylogenetic relationships remain unclear.

Cynoglossum s.l. (excluding the North American Cynoglossum species) forms a clade together with the remaining genera included in the present study. Although the polytomies obtained in Weigend \& al. (2013) are here largely resolved, most nodes are unsupported, and Lindelofia, Mattiastrum, Microparacaryum, Paracaryum, Pardoglossum, Rindera, Solenanthus and Trachelanthus are retrieved as either para- or polyphyletic and/or nested in Cynoglossum s.str. as already suggested in Selvi \& al. (2011).

Main subdivisions in Cynoglosseae s.l. and the placement of the problematic genera. - The phylogenetic analyses based on sequences from three cpDNA regions successfully resolved some major issues about the monophyly of the main tribes of Boraginaceae and provided more detailed insights into the evolution of the Cynoglosseae s.l. In addition to Echiochileae, Boragineae and Lithospermeae, which were already addressed in Weigend \& al. (2013), at least six additional tribes were supported within Cynoglosseae s.1.: (1) Trichodesmeae, (2) Asperugeae, (3) Rochelieae, (4) Craniospermeae, (5) Myosotideae (incl. Trigonotideae), and (6) Cynoglosseae ("Core Cynoglosseae" in Figs. 2, 5). Several subtribes are proposed, especially in Cynoglosseae. Since Omphalodes s.str. can not be included in any of the existing tribes, a new tribe must be created to include its type species and its allies.

In Cynoglosseae s.1., the Trichodesmeae (Caccinia, Trichodesma) and the Lasiocaryum-clade (Chionocharis, Lasiocaryum, Microcaryum) from Africa and East and Central Asia, respectively, are sister clades representing extremely different vegetative, floral and fruit morphologies. Hence, we also propose the recognition of a new tribe Lasiocaryeae to accommodate the genera of the Lasiocaryum-clade.

Asperugeae can be expanded to include Asperugo, Memoremea and Mertensia. Anoplocaryum also belongs here, is monophyletic and sister to Mertensia, but this exact relationship seems uncertain as the crown node of Mertensia is not supported.

Rochelieae includes two subclades, one with Heterocaryum A.DC. and Suchtelenia Karel. ex Meisn. and the other with Eritrichium Schrad. ex Gaudin, Hackelia, Lappula, and Rochelia. None of the newly studied enigmatic genera belongs in this tribe.

Craniospermeae is defined as a monogeneric tribe restricted to Central and East Asia and is closely related to the expanded Myosotideae and the Core-Cynoglosseae.

The expanded Myosotideae including Brachybotrys + Trigonotis and Decalepidanthus + Myosotis is a mostly Eurasian clade, with Trigonocaryum deeply nested in Myosotis. The paraphyletic tribe "Trigonotideae" should be abandoned, as proposed by Weigend \& al. (2010): its type Trigonotis radicans (A.DC.) Steven (Riedl, 1968; Van Royen, 1975: 82) and the sister taxon Brachybotrys are included in Myosotideae. The relationships of Omphalotrigonotis W.T.Wang (two species) previously included in "Trigonotideae" by Riedl (1997), remain uncertain. Other 
genera have already been shown to belong in separate lineages: Mertensia+Omphalodes + Rochelieae (= Eritrichieae s.str.) in a separate clade of the Cynoglosseae s.l. (Weigend \& al., 2013; this study), Bothriospermum embedded in the Core-Cynoglosseae (Weigend \& al., 2013, this study), Ogastemma Brummitt and Sericostoma Stocks ex Wright in the Echiochileae (Långström \& Chase, 2002), and Moltkiopsis I.M.Johnst. and Neatostema I.M.Johnst. in the Lithospermeae (Thomas \& al., 2008; Cecchi \& Selvi, 2009; Weigend \& al., 2009).

The Cynoglosseae (Core-Cynoglosseae in Figs. 2, 5) includes the remaining genera in four well-supported subclades: African Afrotysonia glochidiata and Cynoglossum amplifolium are sister to the Asian Microula-clade (including Actinocarya and Metaeritrichium), which is here formalized as subtribe Microulinae. Additional sampling in African Cynoglossum and Afrotysonia is clearly required to establish genus limits. This tribe is in turn sister to the Cryptantha-clade, or subtribe Amsinckiinae. Resolution and sampling at the base of this group clearly requires additional work. Cryptantha s.l. is non-monophyletic in published analyses (Hasenstab-Lehman \& Simpson, 2012; Weigend \& al., 2013, this study). Cynoglossum and related genera are also para- or polyphyletic. The morphological characters used in the classification of major phylogenetic lineages within Cynoglossum s.l. and Cryptantha s.l. must be re-evaluated, as the characters used historically appear to be symplesiomorphic. Hasenstab-Lehman \& Simpson (2012) provided morphological synapomorphies for Cryptantha s.str. and segregate genera, but the search for definitive synapomorphies for each of the Cryptantha clade genera must be delayed pending further phylogenetic analyses with more comprehensive sampling.

Finally, the Bothriospermum-clade is retrieved as sister to the Cynoglossum s.l. clade and these are here formalized as Bothriosperminae and Cynoglossinae, respectively. Bothriosperminae include Bothriospermum with Thyrocarpus sampsonii, Nihon akiensis and $N$. japonica. Further analyses with an expanded sampling are here required, but we assume that Sinojohnstonia Hu and Antiotrema also belong to this clade (based on ITS data available upon request, Antiotrema forms a well-supported clade with Bothriospermum and Thyrocarpus). Cynoglossinae are well-supported, but internal resolution is nearly non-existant. Extensive additional data will be required to resolve evolutionary relationships and genus limits.

\section{GORMAL TAXONOMY}

The infrafamilial classification for the Boraginaceae proposed here represents the consensus classification at the levels of the subfamily, tribe and subtribe, with all genera assigned to the corresponding units. Names of suprageneric entities are taken from Reveal (1995-). Since in some cases unequivocal data on genus limits and affinities are still wanting, a full consensus could not be reached. A comprehensive list of genus names is provided, including putative synonyms. Accepted genera are highlighted in bold. Accepted genera or synonyms not truly supported by molecular data are indicated by an "*" before the genus name. Genera dubiously assigned to tribes/ subtribes (molecular and/or morphological data insufficient and/or equivocal) are given at the end of the genus list and separated by a " - ? -". A summary of this classification is presented in Table 1.

\section{Conspectus of the infrafamilial classification of Boraginaceae}

1 Echiochiloideae Weigend

2 Boraginoideae Arn.

$2.1 \quad$ Boragineae Rchb.

2.1.1 Boragininae G.Don

2.1.2 Moritziinae Weigend

2.2 Lithospermeae Dumort.

3 Cynoglossoideae Weigend

3.1 Trichodesmeae Zakirov ex Riedl

3.2 Lasiocaryeae Weigend

3.3 Asperugeae Zakirov ex Ovczinnikova

3.4 Omphalodeae Weigend

3.5 Rochelieae A.DC.

3.5.1 Eritrichiinae Benth. \& Hook.f.

3.5.2 Heterocaryinae Riedl

3.6 Craniospermeae DC. ex Meisn.

3.7 Myosotideae Rchb.f.

3.8 Cynoglosseae W.D.J.Koch

3.8.1 Cynoglossinae Dumort.

3.8.2 Bothriosperminae Riedl

3.8.3 Microulinae Weigend

3.8.4 Amsinckiinae Brand

1. Subfam. Echiochiloideae Weigend, subfam. nov. $\equiv$ Echiochilinae Riedl in Rechinger, Fl. Iranica 48: $57.1967 \equiv$ Echiochileae Långström \& M.W.Chase in Långström, Syst. Echiochilon \& Ogastemma (Boraginac.), Phylogeny Boraginoideae Paper 2: 5.2002 - Type: Echiochilon Desf. $=$ Antiphytinae Riedl in Rechinger, Fl. Iranica 48: 53. $1967-$ Type: Antiphytum DC. ex Meisn.

Genera: Antiphytum DC. ex Meisn. 1840 (incl. Amblynotopsis J.F.Macbr. 1916, Amphibologyne Brand 1931, Chamissoniophila Brand 1929), Echiochilon Desf. 1798 (incl. Chilechium Pfeiff. 1873, Chilochium Raf. 1921, Echiochilopsis Caball. 1935, Exioxylon Raf. 1838, Leurocline S.Moore 1901, Sericostoma Stocks 1848, Tetraedrocarpus O.Schwartz 1939), Ogastemma Brummitt 1982 (incl. Megastoma (Benth. \& Hook.f.) Coss. \& Durieu ex Bonnet \& Barratte 1895, nom. illeg., non Megastoma Grassi 1881).

Erect shrublets, rarely herbs, leaves opposite basally or throughout, small, narrowly ovate or obovate or linear, sessile to subsessile, indumentum dense, often sericeous and appressed, sometimes hispid and/or glandular. Flowers subsessile to shortly pedicellate; calyx divided nearly to base, sometimes asymmetrical and tetramerous, lobes mostly unequal; corolla actinomorphic or zygomorphic, tube narrow, sometimes curved, faucal scales absent, but throat with ciliate or papillate appendages or invaginations; gynobase flat or shortly pyramidal. Nutlets smooth, rugose or verrucose, not or 
laterally compressed, often with narrowed base, ventrally and sometimes dorsally keeled, cicatrix at lower end of ventral keel or terminating a downward-projecting stipitate prolongation at base, erect or incurved.

This basally branching clade comprises three genera and ca. 30 species. It has been treated in several studies in the past (Lönn, 1999; Långström \& Chase, 2002; Långström \& Oxelmann, 2003) and is very well supported; it falls into two subclades, one comprising Antiphytum and Ogastemma, the other one representing Echiochilon. These genera are distributed in North Africa and West Asia, with Antiphytum disjunctly distributed between SW North America and SE South America. The species grow in arid environments such as semi-deserts and deserts. They are shrubs and herbs with small flowers that lack faucal and basal scales. The nutlets are also small, verrucose, roughly ovoidal and variable in attachment, ranging from a stipitate basal attachment with an ovate cicatrix to a basiventral attachment with a large, triangular scar, sometimes with concave sides. Indument is sericeous rather than hispid.

2. Subfam. Boraginoideae Arn., Botany [preprint from Encycl. Brit., ed. 7, 5]: 122. 1832 ("Borageae") - Type: Borago L.

This subfamily comprises two tribes, both of which are predominantly Mediterranean but are also found in East Asia, South Africa, and the Americas. Their sister relationship has repeatedly been confirmed in molecular studies. Flowers are often large, mostly with faucal and basal scales. The nutlets in this subfamily are generally roughly ovoidal to

Table 1. Summary of the infrafamilial classification of Boraginaceae proposed in this study (see taxon authorities in the main text).

\begin{tabular}{|c|c|c|c|c|}
\hline Subfamily & Tribe & Subtribe & Accepted genera* & $\begin{array}{l}\text { Approx. no. } \\
\text { of species }\end{array}$ \\
\hline Echiochiloideae & & & Antiphytum (10-15/2), Echiochilon (14/1), Ogastemma & 30 \\
\hline \multirow[t]{3}{*}{ Boraginoideae } & Boragineae & Boragininae & $\begin{array}{l}\text { Anchusa (35/1), Anchusella, Borago (5/1), Brunnera (3/1), Cynoglot- } \\
\text { tis, Gastrocotyle, Hormuzakia, Lycopsis (2/1), Melanortocarya, Nonea, } \\
\text { Pentaglottis (1/1), Phyllocara, Pulmonaria (17/1), Symphytum } \\
(35 / 2), \text { Trachystemon (1/1) }\end{array}$ & 140 \\
\hline & & Moritziinae & Moritzia (3/1), Thaumatocaryon & 6 \\
\hline & Lithospermeae & & 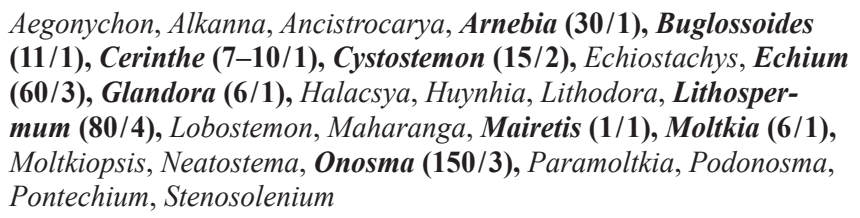 & 460 \\
\hline \multirow[t]{12}{*}{ Cynoglossoideae } & Trichodesmeae & & Caccinia $(6 / 2)$, Trichodesma $(40-50 / 3)$ & 50 \\
\hline & Lasiocaryeae & & Chionocharis (1/1), Lasiocaryum (3/2), Microcaryum (1/1) & 5 \\
\hline & Asperugeae & & $\begin{array}{l}\text { Anoplocaryum (5/2), Asperugo (1/1), Memoremea (1/1), Mertensia } \\
(40 / 5)\end{array}$ & 50 \\
\hline & Omphalodeae & & $\begin{array}{l}\text { Gyrocaryum, Iberodes, Mimophytum, Myosotidium (1/1), Omphalodes } \\
(\mathbf{2 0 - 3 0 / 7 ) , ~ S e l k i r k i a , ~ [ i n c l . ~ M a p u c h e a ] ~}\end{array}$ & 35 \\
\hline & Rochelieae & Eritrichiinae & $\begin{array}{l}\text { Eritrichium }(50 / 5), \text { Hackelia }(45 / 6), \text { Lappula }(50-60 / 5), \text { Lepechini- } \\
\text { ella, Rochelia }(\mathbf{1 5 / 3 )}\end{array}$ & 200 \\
\hline & & Heterocaryinae & Heterocaryum (6/1), Suchtelenia (1/1) & 7 \\
\hline & Craniospermeae & & Craniospermum (6/5) & 6 \\
\hline & Myosotideae & & $\begin{array}{l}\text { Brachybotrys (1/1), Decalepidanthus }(7 / 3), \text { Myosotis }(80-100 / 1), \\
\text { Trigonotis (60/4), [Omphalotrigonotis] }\end{array}$ & 160 \\
\hline & Cynoglosseae & Cynoglossinae & $\begin{array}{l}\text { Cynoglossum (80-100/17), Microparacaryum }(3 / 1)[\text { Lindelofia } \\
(10-20 / 3), \text { Mattiastrum }(50 / 1), \text { Paracaryum }(10-15 / 4), \text { Rindera } \\
(20-25 / 2), \text { Solenanthus }(10 / 2)]\end{array}$ & 200 \\
\hline & & Bothriosperminae & $\begin{array}{l}\text { Antiotrema, Bothriospermum }(5 / 2), \text { Nihon }(5 / 2), \text { Thyrocarpus }(3 / 1), \\
\text { [Sinojohnstonia }]\end{array}$ & 14 \\
\hline & & Microulinae & Afrotysonia (3/1), Microula (30/3), [Adelocaryum $]$ & 36 \\
\hline & & Amsinckiinae & 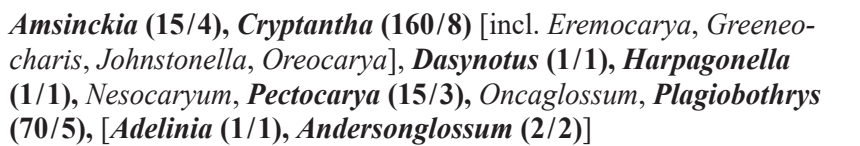 & 300 \\
\hline
\end{tabular}

\footnotetext{
*Genera included in the phylogenetic analyses are highlighted in bold (approximate total number of species per genus/number of species included in the analyses). In squared brackets are those genera whose synonymy and/or taxonomic assignment is still unclear (see Formal Taxonomy section).
} 
triangular-ovoidal, sometimes incurved, smooth or verrucose, and are basally attached on a flat gynobase.

The Boraginoideae comprises 42 genera and ca. 600 species, most of them in the tribe Lithospermeae.

2.1 Tr. Boragineae Rchb., Fl. Germ. Excurs. 1: 340. 1831 Type: Borago L.

$=$ Anchuseae W.D.J.Koch, Syn. Fl. Germ. Helv.: 497. 1837 Type: Anchusa L.

$=$ Symphyteae D.Don in Edinburgh New Philos. J. 13: 240. 1832 - Type: Symphytum L.

Perennial, rarely annual herbs, sometimes rhizomatous or tuberous; plants hispid, rarely sericeous. Leaves often cauline and basal, mostly large and widely ovate-acuminate, distinctly petiolate or with decurrent leaf bases. Calyx united for most of its length or deeply divided, mostly tubular-cylindrical at anthesis, often accrescent in fruit; corolla radially symmetrical or rarely zygomorphic, infundibular to hypocrateriform, rarely rotate, faucal scales large, conspicuous, often exserted from throat, in one or rarely two series, pubescent or papillose; stamens usually 5. Nutlets 1 or 4 , erect or incurved, more or less laterally compressed, usually tessellate and papillose, ventrally keeled, areola basal.

Tribe Boragineae comprises 17 genera and ca. 150 species. It has long been recognized as a distinct group, with some recent modifications, such as the inclusion of American Thaumatocaryon and Moritzia (Weigend \& al., 2009), which are sister to the remainder of the tribe. Their center of diversity is in the Mediterranean, with a few outliers in Africa, Central and East Asia and South America. The clade comprises exclusively herbs from both mesic and semi-arid environments, including numerous herbs from forest and montane habitats. Flowers are mostly large and have well-developed faucal and basal scales. The indument of Boragineae is usually strikingly coarse and hispid.

2.1.1 Subtr. Boragininae G.Don, Gen. Hist. 4: 307, 309. $1837-$ 1838 - Type: Borago L.

= Anchusinae Dumort., Fl. Belg.: 40. 1827 ("Anchuseae") Type: Anchusa L.

= Pulmonarinae Dumort., Fl. Belg.: 41.1827 ("Pulmonarieae") - Type: Pulmonaria L.

= Symphytinae D.Don in Sweet, Hort. Brit., ed. 3: 489. 1839

("Symphyteae") - Type: Symphytum L.

Genera: Anchusa L. 1753 (incl. Buglossum Mill. 1754), Anchusella Bigazzi, Nardi \& Selvi 1997, Borago L. 1753 (incl. Buglossites Moris 1845), Brunnera Steven 1851, Cynoglottis (Guşul.) Vural \& Kit Tan 1983, Gastrocotyle Bunge 1849, Hormuzakia Guşul. 1923, Lycopsis L. 1753 (incl. Buglossa Gray 1821, Echioides Fabr. 1759, Oskampia Baill. 1890, nom. illeg., non Oskampia Moench 1794), Melanortocarya Selvi, Bigazzi, Hilger \& Papini 2006, Nonea Medik. 1789 (incl. Elizaldia Willk. 1852, Massartina Maire 1925, Nephrocarya P.Candargy 1897), Pentaglottis Tausch 1829 (incl. Caryolopha Fisch. \& Trautv. 1837, nom. illeg. superfl.), Phyllocara Guşul. 1927, Pulmonaria L. 1753 (incl. Bessera Schult. 1829, Paraskevia W.Sauer \& G.Sauer 1980), Symphytum L. 1753 (incl. Procopiania Guşul. 1928, × Procopiphytum Pawł. 1971), Trachystemon
D.Don 1832 (incl. Nordmannia Ledeb. ex Nordm. 1837, Psilostemon DC. 1846).

Perennial, rarely annual herbs, sometimes rhizomatous or tuberous; plants hispid, rarely sericeous. Leaves often cauline and basal, mostly large and widely ovate-acuminate, distinctly petiolate or with decurrent leaf bases. Calyx united for most of its length or deeply divided, mostly tubular-cylindrical at anthesis, often accrescent in fruit; corolla radially symmetrical or rarely zygomorphic, infundibular to hypocrateriform, rarely rotate, faucal scales usually large, conspicuous, often exserted from throat, in one or rarely two series, pubescent or papillose; stamens usually 5 . Nutlets 4 , dispersed separately, erect or incurved, more or less laterally compressed, usually tessellate and papillose, ventrally keeled, base widened into broad, collar-like ring and with large, white elaiosome (from gynobase tissue), areola basal.

Subtribe Boraginineae comprises 15 genera and ca. 140 species. It has long been been recognized as a distinct group, mostly at the tribe level (e.g., Guşuleac, 1923, 1928; Riedl, 1963; Hilger \& al., 2004). The phylogeny of the subtribe is not fully resolved to date. Its center of diversity is in the Mediterranean and the Middle East, with a few outliers in Africa, Central and East Asia.

\subsubsection{Subtr. Moritziinae Weigend, subtr. nov. - Type: Moritzia DC. ex Meisn.}

Genera: Moritzia DC. ex Meisn. 1840 (incl. Meratia A.DC. 1846, nom. illeg., non Meratia Cassini 1824), Thaumatocaryon Baill. 1890.

Perennial rosette herbs, often stoloniferous; plants hispid, rarely sericeous. Leaves cauline and basal, large and widely ovate-acuminate, sessile, rosette leaves sometimes petiolate. Calyx deeply divided, tubular-cylindrical at anthesis, slightly accrescent in fruit; corolla radially symmetrical, infundibular to hypocrateriform, faucal scales large, conspicuous, exserted from throat, in one series, pubescent or papillose; stamens 5. Nutlets 1, remaining enclosed in calyx and dispersed with it, erect or laterally compressed, usually papillose, ventrally keeled, base narrowed and stipitate, areola basal.

Moritziinae comprises two genera and ca. six species (Weigend \& al., 2009). They represent rosette herbs from at least seasonally moist grasslands disjunctly distributed between southeastern South America and the Andes (Peru to Costa Rica, only M. lindenii Benth. ex Gürke), the flowers are mostly large, blue and have well-developed faucal and basal scales. Inflorescences are dense thyrsoids and the fruits consist of a single, ventrally and dorsally keeled nutlet enclosed into and dispersed with the calyx.

2.2 Tr. Lithospermeae Dumort., Fl. Belg.: 39. 1827 - Type: Lithospermum $\mathrm{L}$.

$=$ Alkanninae Popov ex Riedl in Rechinger, Fl. Iranica 48: 215. 1967 - Type: Alkanna Tausch

= Cerintheae Dumort., Anal. Fam. Pl.: 25. 1829 - Type: Cerinthe L.

$=$ Echieae Dumort., Fl. Belg.: 42. $1827 \equiv$ Echiinae DC., Prodr. 9: 467.1845 ("Echieae") - Type: Echium L. 
$=$ Moltkiopsidinae Riedl in Rechinger, Fl. Iranica 48: 54. 1967

- Type: Moltkiopsis I.M.Johnst.

Genera: Aegonychon Gray 1821 (incl. Margarospermum (Rchb.) Opiz 1839, Rhytispermum Link 1829), Alkanna Tausch 1824 (incl. Baphorhiza Link 1829, Camptocarpus Decne. 1844, Campylocaryum DC. ex A.DC. 1846, Onochilis Mart. 1817), Ancistrocarya Maxim. 1872, Arnebia Forssk. 1775 (incl. Arnebiola Chiov. 1929, Dioclea Spreng. 1824, Leptanthe Klotzsch 1862, Macrotomia DC. 1840, Meneghinia Endl. 1839, Munbya Boiss. 1849, Strobila G.Don 1837, Tetaris Lindl. 1868, Toxostigma A.Rich. 1850), Buglossoides Moench 1794, Cerinthe L. 1753, Cystostemon Balf.f. 1884 (incl. Vaupelia Brand 1914), Echiostachys Levyns 1934, Echium L. 1753 (incl. Argyrexias Raf. 1838, Isoplesion Raf. 1838, Larephes Raf. 1838, Megacaryon Boiss. 1875, Stomotechium Lehm. 1818), Glandora D.C.Thomas, Weigend \& Hilger 2008, Halacsya Dörfl. 1903 (incl. Zwackhia Sendt. 1858), Huynhia Greuter 1981 (incl. Aipyanthus Steven 1851, Echioides Ortega 1773), Lithodora Griseb. 1844, Lithospermum L. 1753 (incl. Batschia J.F.Gmel. 1794, Cyphorima Raf. 1819, Lasiarrhenum I.M.Johnst. 1924, Macromeria D.Don 1832, Nomosa I.M.Johnst. 1954, Onosmodium Michx. 1803, Osmodium Raf. 1808, nom. illeg. superfl., Pentalophus A.DC. 1846, Perittostema I.M.Johnst. 1954, Psilolaemus I.M.Johnst. 1954, Purshia Spreng. 1817, nom. illeg., non Purshia DC. ex Poir. 1816, Ulugbekia Zakirov 1961), Lobostemon Lehm. 1830 (incl. Echiopsis Rchb. 1837, Isorium Raf. 1837, Lobostema Spreng. 1830, Oplexion Raf. 1838, Penthysa Raf. 1838, Traxara Raf. 1838), Maharanga DC. 1846, Mairetis I.M.Johnst. 1953, Moltkia Lehm. 1817 (incl. Gymnoleima Decne. 1844), Moltkiopsis I.M.Johnst. 1953, Neatostema I.M.Johnst. 1953, Onosma L. 1762 (incl. Colsmannia Lehm. 1818, Coriantha Riedl 1961 ("Choriantha"), Sava Adans. 1763), Paramoltkia Greuter 1981, Podonosma Boiss. 1849, Pontechium Böhle \& Hilger 2000, Stenosolenium Turcz. 1840.

Annual to perennial herbs, subshrubs or shrubs, rarely rhizomatous or stoloniferous. Leaves alternate throughout, small to very large, linear to widely ovate or elliptical, sub-sessile, indumentum often hispid, rarely sericeous and appressed or glandular, rarely glabrous (Cerinthe). Flower subsessile to pedicellate; calyx divided nearly to base to largely united, lobes usually equal; corolla radially symmetrical or zygomorphic, then tube wide, faucal scales often present and well-developed, but sometimes missing and replaced by pubescent or glandular patches; gynobase flat. Nutlets hard and walls incrusted with calcium carbonate, often smooth and shiny, sometimes perforate, foveate, rugose or verrucose, often white or beige, rarely brownish or mottled, sometimes incurved or laterally compressed, often with narrowed base, ventrally and sometimes dorsally keeled, widely ovoid to subspherical.

This tribe comprises 25 genera and ca. 460 species. It has been treated in a range of studies, resolving many genus limits and intergeneric relationships, but failing to resolve the phylogeny of the entire tribe satisfactorily (e.g., Thomas \& al., 2008; Cecchi \& Selvi, 2009; Selvi \& al., 2009; Weigend \& al., 2009). Most genera and all the basal clades in Lithospermeae are restricted to or most diverse in the Mediterranean and
Irano-Turanian regions, a handful of genera are endemic to East Asia (Ancistrocarya, Maharanga) or Africa (Echiostachys, Lobostemon), while Lithospermum is most diverse in the Americas. They are vegetatively heterogeneous, but the majority of the genera are shrublets or shrubs, some predominantly or frequently herbaceous, a few mostly annual. Larger shrubs and rosette trees are found in both Lithospermum and in Echium and allies. Flowers are quite variable, sometimes zygomorphic, and the presence or absence of faucal and basal scales is quite variable. Nutlets are rough or smooth and have a strongly mineralized pericarp, their attachment is always basal with a usually subcircular cicatrix, an elaiosome is generally absent.

\section{Subfam. Cynoglossoideae Weigend, subfam. nov. - Type: Cynoglossum L. \\ Annual or perennial herbs, sometimes minute and ephem-} eral, rarely subshrubs or shrubs, sometimes rhizomatous or stoloniferous, basal leaf rosette sometimes present, leaves and indumentum variable. Calyx variously united, often only in lower third, rotate to campanulate, sometimes accrescent in fruit; corolla radially symmetrical, mostly hypocrateriform or infundibuliform, faucal scales large, conspicuous, often exserted from throat, pubescent or papillose, rarely glabrous or absent; stamens equal or rarely unequal; gynobase widely to narrowly pyramidal to subulate, rarely almost flat. Nutlets 1-4(-10), straight or spreading, rarely recurved (never incurved), often oblique with apex close to style base and nutlet base widely divergent, dorsiventrally compressed, sometimes ventrally keeled, rarely ovoid to subcylindrical or lenticellate, then usually with ventral keel, variously papillose or glochidiate, rarely smooth, often with distinct dorsomarginal wing, wing spreading or erect to incurved, nutlets usually with ovate to triangular cicatrix, often in median or subapical position, rarely basal, elaiosome usually absent. Nutlets dispersed singly or remaining enclosed in accrescent calyx or attached to the calyx or the plant.

Cynoglossoideae is by far the largest subfamily comprising over 900 species in around 50 genera. Recent molecular studies have shown that a wide range of previously recognized tribes falls into this clade. Flowers are extremely variable, showing no common patterns. The gynobase, however, is usually pyramidal to subulate and the nutlets nearly universally show ventral attachment. There are only few genera with basal attachment, then nutlets are variable in shape, but are dorsiventrally compressed (lentil-shaped or rhomboidal), or otherwise have lateral to dorsal wings or rings, a character not found elsewhere in Boraginaceae.

3.1 Tr. Trichodesmeae Zakirov ex Riedl in Rechinger, Fl. Iranica 48: 219. 1967 - Type: Trichodesma R.Br.

Genera: Caccinia Savi 1832 (incl. Anisanthera Raf. 1836, Heliocarya Bunge 1871), Trichodesma R.Br. 1810, nom. cons. (incl. Boraginella Siegesb. ex Kuntze 1891, Boraginodes T.Post \& Kuntze 1903, Borraginoides Moench 1794, Friedrichsthalia Fenzl 1839, Lacaitaea Brand 1914, Leiocarya Hochst. 1844, Octosomatium Gagnep. 1950, Pollichia Medik. 1783-1784, nom. rej., Spiroconus Stev. 1851, Streblanthera Steud. 1844). 
Robust perennial or biennial herbs, often (sometimes tall) shrubs; plants hispid to sericeous, sometimes glaucous. Leaves elliptical to obovate, subsessile. Calyx divided to base or to the middle; corolla often rotate or hypocrateriform with short tube, radially symmetrical or slightly zygomorphic. Anthers exserted from the usually short tube. Nutlets often 1 or up to 4 , large to very large, oblique to horizontal, dorsiventrally compressed and usually distinctly glochidiate and winged, areola medial and ventral.

Trichodesmeae comprise only two genera and ca. 50 species. They are essentially western Eurasian and African and consist mostly of coarse, perennial herbs and shrubs, including the largest members of the family (Trichodesma scottii from Socotratree to $5 \mathrm{~m}$ tall). Flowers are extremely variable, with those of Trichodesma conforming to the Solanum-type, and those of Caccinia with free anthers in an asymmetrical androecium.

\subsection{Tr. Lasiocaryeae Weigend, tr. nov. - Type: Lasiocaryum I.M.Johnst.}

Genera: Chionocharis I.M.Johnst. 1924, Lasiocaryum I.M.Johnst. 1925 (incl. Oreogenia I.M.Johnst. 1924, nom. illeg., non Orogenia S.Watson 1871, Setulocarya R.R.Mill \& D.G.Long 1996), Microcaryum I.M.Johnst. 1924.

Minute annual herbs or perennial cushion plants, plants with soft, often sericeous indument. Leaves elliptical to obovate, subsessile. Calyx divided nearly to base; corolla hypocrateriform, radially symmetrical. Anthers included. Nutlets 4, minute, erect, ovoidal, rugose or pubescent, areola suprabasal and ventral.

Lasiocaryeae comprise only three genera and five species. They are essentially Himalayan and are small to tiny annual or perennial herbs, often less than $5 \mathrm{~cm}$ when fully developed. A highly natural group which is strongly divergent from its closest ally, Trichodesmeae, in size and vegetative, floral and fruit morphology.

3.3 Tr. Asperugeae Zakirov ex Ovczinnikova in Bot. Zhurn. (Moscow \& Leningrad) 92: 755. 2007 Asperuginae Riedl in Rechinger, Fl. Iranica 48: 95. 1967 - Type: Asperugo L. = Anoplocaryinae Ovczinnikova in Bot. Zhurn. (Moscow \& Leningrad) 92: 754. 2007 - Type: Anoplocaryum Ledeb. Genera: Anoplocaryum Ledeb. (1847), Asperugo L. (1753), Memoremea A.Otero, Jim.Mejías, Valcárcel \& P.Vargas 2014, Mertensia Roth 1797, nom. cons. (incl. Casselia Dumort. 1822, Cerinthodes Kuntze 1891, Hippoglossum Hartm. 1832, Oreocharis Lindl. 1847, Platynema Schrad. 1835, Pneumaria Hill 1764, Steenhammera Rchb. 1831, Winkleria Rchb. 1841).

Small to large annual or perennial herbs, often with pleiocorm; indumentum sparse, pubescent or puberulent, often glabrous and glaucous. Flower hypocrateriform or unfundibuliform, faucal scales often absent. Gynobase shallowly pyramidal. Nutlets 4 , oblique on pyramidal gynobase, ovoid to subcircular in dorsal view, weakly dorsiventrally flattened, dorsally more or less convex, flat or concave, brown to black, smooth or irregularly verrucose or rugose, sometimes very indistinctly winged along margins, areola medial, on short \pm distinctive, often oblique stalk.
Asperugeae are a peculiar clade of four well-differentiated genera with a total of ca. 50 species, most in Mertensia. The group was recognized solely on the basis of molecular data in the past few years. It is a Holarctic group, with Asperugo and Memoremea originally western Eurasian, Mertensia Holarctic and Anoplocaryum Central and East Asian. All genera have very small cicatrices and all apart from Memoremea have oblique, \pm stipitate nutlet attachment on a very shortly pyramidal gynobase.

\subsection{Tr. Omphalodeae Weigend, tr. nov. - Type: Omphalodes} Mill.

Genera: Gyrocaryum Valdés 1983, Iberodes M.Serrano, R.Carbajal \& S.Ortiz 2016, Mimophytum Greenm. 1905, Omphalodes Mill. 1754 (incl. Omphalium Wallr. 1822, nom. illeg. superfl., Picotia Roem. \& Schult. 1819, Umbilicaria Heist. ex Fabr. 1759), Myosotidium Hook. 1859, Selkirkia Hemsl. 1884 (incl. Mapuchea M.Serrano, R.Carbajal \& S.Ortiz 2016).

Medium-sized to large annual or perennial herbs, often rhizomatous. Indumentum pubescent or leaves at least adaxially glabrous. Leaves ovate to oblong, basal leaves (if present) petiolate. Corolla hypocrateriform; gynobase mostly widely pyramidal. Nutlets 4, rarely 1 , oblique or horizontal on gynobase, ovoid to subcircular, mostly dorsiventrally flattened and (sometimes deeply) concave, rarely convex, glabrous or pubescent, sometimes glochidiate, cicatrix of moderate size and in median position, ovate to elliptical.

Tribe Omphalodeae comprises six genera and ca. 35 species. This small tribe is western Eurasian, present with a handful of species in SW North America, the Andes to Chile and have one endemic representative each on the Juan Fernandez and the Chatham Islands.

3.5 Tr. Rochelieae A.DC., Prodr. 10: 175. 1846 - Type: Rochelia Rchb., nom. cons.

$=$ Eritrichieae Gürke in Engler \& Prantl, Nat. Pflanzenfam. IV(3a): 81. 1893 - Type: Eritrichium Schrad. ex Gaudin.

$=$ Heterocaryeae Zakirov ex Ovczinnikova in Bot. Zhurn. (Moscow \& Leningrad) 92: 755. 2007 - Type: Heterocaryum A.DC.

Small to medium-sized annual or perennial herbs, sometimes ephemeral or cushion-forming. Indumentum mostly hispid, sometimes pubescent, sericeous or villous. Calyx usually divided nearly to base; corolla hypocrateriform to infundibuliform, generally small to very small; gynobase (narrowly) pyramidal to subulate, rarely widely pyramidal. Nutlets 1-4, oblique on pyramidal gynobase or parallel on subulate gynobase, ovate to subcircular in dorsal view, mostly dorsiventrally compressed and with distinct glochidiate rim, rarely only verrucose or nearly smooth, cicatrix triangular or triangular-ovate, medial.

The group is a well-supported clade with a center of diversity in Central and West Asia, but present on all continents. Most species are annual or perennial herbs from seasonally arid habitats, with some high montane and subarctic, cushionforming plants (Eritrichium) and more mesic forest groups 
(some Hackelia). The basally branching clade is here segregated as Heterocaryinae, represented by two essentially Central Asian genera.

\subsubsection{Subtr. Eritrichiinae Benth. \& Hook.f., Gen. Pl. 2: 835.} 1876 ("Eritrichieae") - Type: Eritrichium Schrad. ex Gaudin.

= Echinosperminae Ovczinnikova in Bot. Zhurn. (Moscow \& Leningrad) 90: 1157. 2005 - Type: Echinospermum Sw. ex Lehm.

= Rocheliinae Riedl in Rechinger, Fl. Iranica 48: 89. 1967 Type: Rochelia Rchb., nom. cons.

Genera: Eritrichium Schrad. ex Gaudin 1828 (incl. Amblynotus I.M.Johnst. 1924, Sauria Bajtenov 1996, *Tianschaniella B.Fedtsch. 1951), Hackelia Opiz 1839 (incl. Austrocynoglossum Popov ex R.R.Mill 1989, Embadium J.M.Black 1931), Lappula Moench 1794 (incl. Cynoglossospermum Kuntze 1891, Echinospermum Sw. ex Lehm. 1818, Omphalolappula Brand 1931, Sclerocaryopsis Brand 1931), Lepechiniella Popov 1953, Rochelia Rchb. 1824, nom. cons. (incl. Cervia Rodrig. ex Lag. 1816, Raclathris Raf. 1838).

Small to medium-sized annual or perennial herbs, sometimes ephemeral or cushion-forming. Indumentum mostly hispid, sometimes pubescent, sericeous or villous. Calyx usually divided nearly to base; corolla hypocrateriform to infundibuliform; anthers included; gynobase (narrowly) pyramidal to subulate. Nutlets $1-4$, oblique on pyramidal gynobase, ovate to subcircular in dorsal view, glochidiate, often with a thickened, glochidiate margin, rarely only verrucose or nearly smooth, cicatrix triangular or triangular-ovate, medial.

Eritrichiinae comprise five ill-defined genera with over 200 species overall, which still require extensive taxonomic and phylogenetic work both at the species and the genus level. All genera apart from central to western Eurasian Rochelia are widespread in the northern Hemisphere and have several representatives in Australia and/or South America. The bulk of the species are fastgrowing annuals of xeric habitats. Eritrichium comprises several perennial cushion-plants (Ovchinnikova, 2008) and Hackelia are mostly broad-leaved herbs from mesic habitats. None of the genera is clearly monophyletic and delimitation has to be investigated critically, based on a very broad sampling.

3.5.2. Subtr. Heterocaryinae Riedl in Rechinger Fl. Iranica 48: 84. 1967 - Type: Heterocaryum A.DC.

Genera: Heterocaryum A.DC. 1846, Suchtelenia Karel. ex Meisn. 1840.

Annual herbs with hispid indument, sometimes subglabrous and glaucous. Leaves all cauline (in flower), linear to obovate, sessile. Calyx divided nearly to base or only to half, sometimes strongly accrescent and patelliform in fruit; corolla minute, cylindrical to infundibuliform, blue, faucal scales minute; gynobase columnar or broadly pyramidal, sometimes subulate in fruit, winged between areoles, nutlets oblong, dorsally convex or concave, heteromorphic $(3+1$ or $2+2)$, either with dentate-glochidiate wing or not winged, ventrally deeply immersed in gynobase or permanently attached to gynobase along entire adaxial surface.
Heterocaryinae comprise only two Central Asian genera with seven annual species. Their nutlets are deeply immersed into the variously shaped gynobase and leave a distinct depression of frame after removal or dispersal.

3.6 Tr. Craniospermeae DC. ex Meisn., Pl. Vasc. Gen. 1: 280; 2: 189. 1840 三 Craniosperminae DC., Prodr. 9: 467. 1845

('Craniospermeae')- Type: Craniospermum Lehm.

Genus: Craniospermum Lehm. 1818 (incl. Diploloma Schrenk).

Biennial or perennial herbs with hirsute to floccose indumentum. Corolla cylindrical, lobes erect to half-spreading, (triangular-)ovate, faucal scales absent, sometimes scale-like emergences between corolla lobes present. Nutlets on a more or less flat gynobase, erect, ovoid, transversely rugose, dorsally or dorso-apically with pseudoaperture with narrow, coriaceous, unequally dentate wing almost closing over dorsal disc, cicatrix basal.

Our molecular data clearly retrieve the genus Craniospermum in an isolated position in Cynoglossoideae. Craniospermeae are restricted to Central Asia and comprise a single genus of ca. six species (Ovchinnikova, 2000).

3.7 Tr. Myosotideae Rchb.f., Icon. Fl. Germ. Helv. 18: 70. 1858 $\equiv$ Myosotidinae Kitt., Taschenb. Fl. Deutschl., ed. 2, 1: 420. 1843 ("Myosotides") - Type: Myosotis L.

= Pseudomertensiinae Riedl in Rechinger, Fl. Iranica 48: 58. 1967 - Type: Pseudomertensia Riedl.

$=$ Trigonocaryeae Kerimov in Bot. Zhurn. (Moscow \& Leningrad) 90: 265. 2005 - Type: Trigonocaryum Trautv.

= Zoellerieae Gürke in Engler \& Prantl, Nat. Pflanzenfam. IV(3a): 81. 1893 - Type: Zoelleria Warb.

Genera: Brachybotrys Maxim. ex Oliv. 1878, Decalepidanthus Riedl 1963 (incl. Pseudomertensia Riedl 1967, Scapicephalus Ovcz. \& Czukav. 1974), Myosotis L. 1753 (incl. Echioides Moench 1794, nom. illeg., non Echioides Fabricius 1759, *Exarrhena R.Br. 1810, *Gymnomyosotis (A.DC.) O.D.Nikif. 2000, Scorpioides Gilib. 1781, *Strophiostoma Turcz. 1840, Trigonocaryum Trautv. 1875), Trigonotis Steven 1851 (incl. Endogonia Lindl. 1847, Havilandia Stapf 1894, Pedinogyne Brand 1925, *Stephanocaryum Popov 1951, Zoelleria Warb. 1892). - ? - *Omphalotrigonotis W.T.Wang 1984.

Tiny to medium-sized annual or perennial herbs, sometimes ephemeral, often rhizomatous or stoloniferous. Indumentum pubescent or puberulent, rarely sericeous or villous. Gynobase nearly flat to shallowly pyramidal. Nutlets 4, rarely fewer or up to 10 , small (<calyx), erect, lenticellate to tetrahedral, usually with lateral, often also with ventral keel, dark brown to black, rarely triangular, glabrous, smooth or papillose, sometimes with distinct dorsal wing, cicatrix circular to elliptical, suprabasal, rarely cicatrix distinctly stalked.

Myosotideae comprise four clear-cut genera (ca. 160 species), three of them essentially Himalayan and East Asian, the fourth-Myosotis - subcosmopolitan with centers of diversity in the Mediterranean and New Zealand. Omphalotrigonotis may belong here. A subdivision of the large genera Trigonotis and Myosotis would require critical revisions and 
near-comprehensive sampling, the available data do not permit the confident recognition of monophyletic entities.

3.8 Tr. Cynoglosseae W.D.J.Koch, Syn. Fl. Germ. Helv.: 496. 1837 - Type: Cynoglossum L.

= Harpagonelleae Baill., Hist. Pl. 10: 366, 390. $1890-$ Type: Harpagonella A.Gray

$=$ Cryptantheae Brand in Repert. Spec. Nov. Regni Veg. 21: 249. 1925 - Type: Cryptantha Lehm. ex G.Don.

Annual or perennial herbs, with sericeous to hispid indument, leaves distinctly or indistinctly petiolate. Corolla usually hypocrateriform, sometimes infundibuliform or cylindrical, basal and faucal scales generally present. Gynobase narrowly to broadly pyramidal, nutlets usually with broad, triangular-ovate scar and ventral attachment, rarely with small suprabasal or basal attachment. Dorsiventrally compressed, often strongly so with concave back and with differentiated margin, sometimes winged, rarely more or less ovoidal, then with a pseudocicatrix on the back (circular or narrow depression), surface granular or more often glochidiate.

3.8.1 Subtr. Cynoglossinae Dumort., Fl. Belg.: 39. 1827 (“Cynoglosseae") - Type: Cynoglossum L.

$=$ Rinderinae G.Don, Gen. Hist. 4: 307, 309. 1837-1838-Type: Rindera Pall.

Genera: Cynoglossum L. pro parte incl. type 1753 (incl. Anchusopsis Bisch. 1852, Bilegnum Brand 1915, Cerinthopsis Kotschy ex Paine 1875, Crucicaryum Brand 1929, Cynoglossopsis Brand 1931, Cyphomattia Boiss. 1875, Ivanjohnstonia Kazmi 1975, Kuschakewiczia Regel \& M.Smirn. 1877, *Lindelofia Lehm. 1850, Mattia Schult. 1809, *Mattiastrum (Boiss.) Brand 1915, *Paracaryum Boiss. 1849, Paracynoglossum Popov 1953, Pardoglossum Barbier \& Mathez 1973, *Rindera Pall. 1771, *Solenanthus Ledeb. 1829, *Trachelanthus Kunze 1850), Microparacaryum (Popov ex Riedl) Hilger \& Podlech 1985 (incl. Brandella R.R.Mill 1986).

Medium-sized to mostly robust perennial, rarely annual or ephemeral herbs, often with distinct basal leaf rosette; indumentum pubescent, sometimes hispid, villous or sericeous. Leaves basal and cauline, rarely cauline only. Calyx divided nearly to base, erect to spreading; corolla hypocrateriform to infundibuliform, rarely cylindrical; gynobase widely pyramidal. Nutlets typically 4 , large, oblique on gynobase, ovateacuminate to subcircular in dorsal view, usually glochidiate all around, rarely glabrous, dorsomarginal rim often differentiated and delimitating a convex back or differentiated into a distinct, flat or incurved wing, cicatrix triangular or triangular-ovate, subapical, rarely central, detachment mostly with "awn"-a sliver of apical gynobase tissue.

Cynoglossinae - in our sampling - comprise only two morphologically well defined clades, Microparacaryum with ca. three species and Cynoglossum s.l. with ca. 200 species. However, there is a whole range of segregate genera that have been proposed for Cynoglossum and their phylogenetic relationships are not at all resolved. Some of them may be monophyletic, but at present all of them appear to be nested in Cynoglossum. The subtribe is entirely restricted to the Old
World, with a center of diversity in western Asia and the Mediterranean. They all share dorsiventrally compressed nutlets, usually with a concave to slightly convex back and a more or less distinct margin. Detailed taxonomic and phylogenetic studies are clearly required to resolve this complex group.

3.8.2 Subtr. Bothriosperminae Riedl in Rechinger, Fl. Iranica 48: 56. 1967 - Type: Bothriospermum Bunge

Genera: Antiotrema Hand.-Mazz. 1920 (incl. Henryettana Brand 1929), Bothriospermum Bunge 1833, Nihon A.Otero, Jim.Mejías, Valcárcel \& P.Vargas 2014, Thyrocarpus Hance 1862. - ? - *Sinojohnstonia Hu 1936.

Small to medium-sized annual or perennial herbs, lax and trailing or compact with distinct basal leaf rosette. Indumentum pubescent, sometimes hispid or villous. Leaves basal and cauline, obovate-acuminate or oblong from cuneate base. Calyx divided nearly to base; corolla hypocrateriform to infundibuliform; gynobase flat, widely pyramidal; style filiform, included, stigma usually capitate. Nutlets typically 4 , erect or incurved on pyramidal gynobase, ovate to circular in dorsal view, usually glochidiate, rarely only verrucose, "dorso-"marginal wing often double, erect or incurved, often much smaller than nutlet diameter ("pseudocicatrix"), displaced into a dorsal-apical or even ventral position, cicatrix triangular or triangular-ovate, medial.

Bothriospermeae comprise four to five genera and 14 species from eastern Asia. Vegetative, floral and fruit morphology represent a perfect continuum and only the assignment of Sinojohnstonia requires confirmation.

\subsubsection{Subtr. Microulinae Weigend, subtr. nov. - Type: Micro- ula Benth.}

Genera: Afrotysonia Rauschert 1982 (incl. Tysonia Bolus 1890, nom. illeg., non Tysonia Fontaine 1889), Microula Benth. 1876 (incl. Actinocarya Benth. 1876, Glochidocaryum W.T.Wang 1957, Metaeritrichium W.T.Wang 1980, Schistocaryum Franch. 1891, Tretocarya Maxim. 1881). - ? - *Adelocaryum Brand 1915 (incl. Paracaryopsis (Riedl) R.R.Mill 1991).

Annual, biennial or perennial herbs, acaulescent or with erect, ascending or prostrate stem; indumentum variable. Calyx divided nearly to base; corolla infundibuliform to hypocrateriform, blue or whitish, faucal scales crescent-shaped; stamens included or widely exserted; gynobase nearly flat. Nutlets erect to spreading, ovoid, rarely turbinate, usually tuberculate, pubescent, rarely glochidiate or setose, sometimes strongly dorsiventrally flattened or concave, or with an abaxial triangular to elliptic pseudoaperture/foveola and adaxially keeled, cicatrix basal, small, circular to elongate.

Microulinae comprise at least two genera and over 30 species species from Africa and the Himalayas. A morphologically heterogenous group, with Afrotysonia providing the morphologically connection to the basal grade of the otherwise highly divergent sister group Amsinckiinae. Generic delimitation of Afrotysonia versus Cynoglossum is clearly in need of revision. Adelocaryum is tentatively placed here, because of its evident similarity to Cynoglossum amplifolium. This requires further study. 
3.8.4 Subtr. Amsinckiinae Brand in Engler, Pflanzenr. IV. 252 (Heft 97): 20. 1931 ("Amsinckieae") - Type: Amsinckia Lehm.

= Harpagonelleae Baill., Hist. Pl. 10: 366, 390. $1890-$ Type: Harpagonella A.Gray

$=$ Allocaryinae Grig. ex Ovczinnikova in Bot. Zhurn. (Moscow \& Leningrad) 92: 753. 2007 - Type: Allocarya Greene

Genera: *Adelinia J.I.Cohen 2015, *Andersonglossum

J.I.Cohen 2015, Amsinckia Lehm. 1831, nom. cons., Cryptantha Lehm. ex G.Don 1837 (incl. *Eremocarya Greene 1887, *Greeneocharis Gürke \& Harms 1899, Hemisphaerocarya Brand 1927, *Johnstonella Brand 1925, Krynitzkia Fisch. \& Mey. 1841, *Oreocarya Greene 1887, Piptocalyx Torr. 1874, Wheelerella G.B.Grant 1906), Dasynotus I.M.Johnst. 1948, Harpagonella A.Gray 1876, Nesocaryum I.M.Johnst. 1927, Pectocarya DC. ex Meisn. 1840 (incl. Ctenospermum T.Post \& Kuntze 1903, Gruvelia A.DC. 1846, Ktenospermum Lehm. 1838), Oncaglossum Sutorý 2010, Plagiobothrys Fisch. \& C.A.Mey. 1836 (incl. Allocarya Greene 1887, Allocaryastrum Brand 1931, Echidiocarya A.Gray ex Benth. \& Hook.f. 1876, Echinoglochin Brand 1925, Glyptocaryopsis Brand 1931, Maccoya F.Muell. 1859, Sonnea Greene 1887).

Annual, biennial or perennial herbs, rarely shrublets, sometimes cespitose with creeping axes rooting at the nodes; indumentum variable, sometimes hispid. Calyx divided nearly to base; corolla infundibuliform to hypocrateriform, white, rarely blue or yellow, faucal scales crescent-shaped; stamens usually included; gynobase narrowly pyramidal. Nutlets erect, spreading or recurved, ovoid, ovoid-acuminate or rarely depressedly globose, usually tuberculate or verrucose, rarely glochidiate, sometimes strongly dorsiventrally flattened or concave, cicatrix ventral, circular to mostly narrowly triangular.

Amsinckiinae is a morphologically heterogeneous but clearly monophyletic group distributed mostly in the Americas with a handful of species of Plagiobothrys in Australia and northeast Asia. Plants are annual or perennial herbs, with a subglabrous to hispid indument. The gynobase is generally pyramidal to cylindrical, with hyperdiversity in nutlet morphology among genera and species, sometimes showing fruit dimorphism or heterocarpy. Nutlets of early diverging taxa are rounded and glochidiate, nutlets of Pectocarya are oblanceolate to linear, smooth, with margins often toothed or winged, and nutlets of Amsinckia, Cryptantha s.1., and Plagiobothrys are ovate to lanceolate, smooth to spinulose, with margins rounded to fully winged.

Traditionally viewed as five genera with over 300 species, our data confirm the phylogenetic results of three previous studies (Weigend \& al., 2013; Cohen, 2014, 2015) that expand Amsinckiinae to include the monospecific Dasynotus daubenmirei and some New World members of Cynoglossum s.l. The basal grade still requires extensive work, with the recently described Andersonglossum polyphyletic in our analysis and placement of Oncaglossum (Cohen, 2015) and Dasynotus unresolved. Our data support the polyphyly of Cryptantha s.1., in which other studies have recognized up to four segregate genera (Hasenstab-Lehman \& Simpson, 2012). Currently, we accept Amsinckiinae as containing eight to fourteen genera, but further research may require recognition of up to nineteen genera within the subtribe so that only monophyletic groups are named.

\section{ACKNOWLEDGEMENTS}

The authors thank S. Dressler and H. Kappes (Senckenberg Forschungsinstitut und Naturmuseum, Germany), for DNA samples of Afrotysonia pilosicaulis, U. Braun (University of Halle, Germany) for herbarium samples of Craniospermum, C. Bräuchler (Technical University Munich, Germany), for silica-gel samples and photos of Afrotysonia glochidiata, W. Lobin and T. Joßberger (Bonn Botanical Gardens, Germany) for photos of Boraginaceae and material collected in Morocco, H.J. Ensikat and N. Schmandt (Nees-Institute für Biodiversität der Pflanzen, Germany), for technical assistance in the SEM and molecular labs, respectively, D. Boufford (Harvard University, U.S.A.), for providing photos of Lasiocaryum and Chionocharis, P. Kosachev (Altai State University, Russia) and N. Stepantsova (Moscow, Russia) for photos of Craniospermum, T. Henning (Freie Universität Berlin, Germany) for photos of Cynoglossum. We also thank all other participants of the second Boraginales Meeting that took place in Bonn in May 2015 for important feedback and discussion. This research received support from the SYNTHESYS project http:// www.synthesys.info/ which is financed by the European Community Research Infrastructure Action under the FP6 "Structuring the European Research Area" (Grant GB-TAF-4514) and FP7 "Capacities" (Grants ES-TAF-136, AT-TAF-2001, FR-TAF-1977, SE-TAF-2567) Programmes.

\section{LITERATURE CITED}

Avetisjan, E.M. 1956. Morphology of the microspores in Boraginaceae. Trudy Bot. Inst. Akad. Nauk Armen. S.S.R. 10: 1-66.

APG III 2009. An update of the Angiosperm Phylogeny Group classification for the orders and families of flowering plants: APG III. Bot. J. Linn. Soc. 161: 105-121. http://dx.doi.org/10.1111/j.1095-8339.2009.00996.x

Bentham, G. 1876. Boragineae. Pp. 832-865 in: Bentham, G. \& Hooker, J.D. (eds.), Genera plantarum, vol. 2(2). Londini [London]: venit apud Lovell Reeve. http://dx.doi.org/10.5962/bhl.title.747

Bolus, H. 1890. Tysonia africana, Bolus. Hooker's Icon.Pl. 20: pl. 1942. http://dx.doi.org/10.5962/bhl.title.16059

Brand, A. 1921. Borraginaceae-Borraginoideae: Cynoglosseae. Pp. 1-183 in: Engler, A. (ed.), Das Pflanzenreich, IV. 252. Leipzig: Engelmann.

Cecchi, L. \& Selvi, F. 2009. Phylogenetic relationships of the monotypic genera Halacsya and Paramoltkia and the origins of serpentine adaptation in circum-mediterranean Lithospermeae (Boraginaceae): Insights from ITS and matK DNA sequences. Taxon 58: 700-714.

Cohen, J.I. 2014. A phylogenetic analysis of morphological and molecular characters of Boraginaceae: Evolutionary relationships, taxonomy, and patterns of character evolution. Cladistics 30: 139-169. http://dx.doi.org/10.1111/cla.12036

Cohen, J.I. 2015. Adelinia and Andersonglossum (Boraginaceae), two new genera from New World species of Cynoglossum. Syst. Bot. 40: 611-619. http://dx.doi.org/10.1600/036364415X688385

Dickoré, W.B. \& Hilger, H.H. 2015. Decalepidanthus (Boraginaceae) 
includes and antedates Pseudomertensia: A synopsis of the genus. Phytotaxa 226: 131-143. http://dx.doi.org/10.11646/phytotaxa.226.2.3

Doyle, J.J. \& Doyle, J.L. 1987. A rapid DNA isolation procedure for small quantities of fresh leaf tissue. Phytochem. Bull. Bot. Soc. Amer. 19: 11-15.

Gottschling, M., Luebert, F., Hilger, H.H. \& Miller, J.S. 2014. Molecular delimitations in the Ehretiaceae (Boraginales). Molec. Phylogen. Evol. 72: 1-6. http://dx.doi.org/10.1016/j.ympev.2013.12.005

Guilliams, C.M. 2015. Diversification, biogeography, and classification of Amsinckiinae (Boraginaceae), with an emphasis on the popcornflowers (Plagiobothrys). Dissertation, University of California, Berkeley, Berkeley, California, U.S.A.

Guşuleac, M. 1923. Beiträge zur Systematik der Anchuseae. Publ. Soc. Nat. România 6: 79-92.

Guşuleac, M. 1928. Die monotypischen und artenarmen Gattungen der Anchuseae (Caryolopha, Brunnera, Hormuzakia, Gastrocotyle, Phyllocara, Trachystemon, Procopiania und Borago). Bul. Fac. Şti. Cernăuţi 2: 394-461.

Hance, H.F. 1862. Manipulus plantarum novarum, potissime chinensium, adjectis notulis nonnullis affinitates, caet., respicientibus. Ann. Sci. Nat., Bot., sér. 4, 18: 217-238.

Hasenstab-Lehman, K.E. \& Simpson, M.G. 2012. Cat's eyes and popcorn flowers: Phylogenetic systematics of the genus Cryptantha s.l. (Boraginaceae). Syst. Bot. 37: 738-757. http://dx.doi.org/10.1600/036364412X648706

Hilger, H.H. 2014. Ontogeny, morphology, and systematic significance of glochidiate and winged fruits of Cynoglosseae and Eritrichieae (Boraginaceae). Pl. Diversity Evol. 131: 167-214. http://dx.doi.org/10.1127/1869-6155/2014/0131-0080

Hilger, H.H., Selvi, F., Papini, A. \& Bigazzi, M. 2004. Molecular systematics of Boraginaceae tribe Boragineae based on ITS1 and $\operatorname{trnL}$ Sequences, with special reference to Anchusa s.l. Ann. Bot. (Oxford) 94: 201-212. http://dx.doi.org/10.1093/aob/mch132

Huelsenbeck J.P. \& Ronquist F. 2001. MRBAYES: Bayesian inference of phylogenetic trees. Bioinformatics 17: 754-755. http://dx.doi.org/10.1093/bioinformatics/17.8.754

Johnston, I.M. 1924. Studies in the Boraginaceae III. 1. The Old World genera of the Boraginoideae. Contr. Gray Herb. 3: 42-73.

Johnston, I.M. 1925. Studies in the Boraginaceae IV. The North American species of Cryptantha. Contr. Gray Herb. 74: 1-114.

Johnston, I.M. 1927. Studies in the Boraginaceae VI. A revision of the South American Boraginoideae. Contr. Gray Herb. 78: 1-118.

Kearse, M., Moir, R., Wilson, A., Stones-Havas, S., Cheung, M., Sturrock, S., Buxton, S., Cooper, A., Markowitz, S., Duran, C., Thierer, T., Ashton, B., Mentjies, P. \& Drummond, A. 2012. Geneious Basic: An integrated and extendable desktop software platform for the organization and analysis of sequence data. Bioinformatics 28: 1647-1649.

http://dx.doi.org/10.1093/bioinformatics/bts199

Kerimov, V.N. \& Askerova, R.K. 2005. On the taxonomic position of the genera Trigonocaryum and Suchtelenia. Bot. Zhurn. (Moscow \& Leningrad) 90: 264-267.

Långström, E. \& Chase, M.W. 2002. Tribes of Boraginoideae (Boraginaceae) and placement of Antiphytum, Echiochilon, Ogastemma and Sericostoma: A phylogenetic analysis based on atpB plastid DNA sequence data. Pl. Syst. Evol. 234: 137-153. http://dx.doi.org/10.1007/s00606-002-0195-z

Långström, E. \& Oxelman, B. 2003. Phylogeny of Echiochilon (Echiochileae, Boraginaceae) based on ITS sequences and morphology. Taxon 52: 725-735. http://dx.doi.org/10.2307/3647347

Lönn, E. 1999. Revision of the three Boraginaceae genera Echiochilon, Ogastemma and Sericostoma. Bot. J. Linn. Soc. 130: 185-259. http://dx.doi.org/10.1111/j.1095-8339.1999.tb00521.x

Luebert, F., Brokamp, G., Wen, J., Weigend, M. \& Hilger, H.H. 2011. Phylogenetic relationships and morphological diversity in Neotropical Heliotropium (Heliotropiaceae). Taxon 60: 663-680.

Luebert, F., Cecchi, L., Frohlich, M.W., Gottschling, M., Guilliams,
C.M., Hasenstab-Lehman, K.E., Hilger, H.H., Miller, J.S., Mittelbach, M., Nazaire, M., Nepi, M., Nocentini, D., Ober, D., Olmstead, R.G., Selvi, F., Simpson, M.G., Sutorý, K., Valdés, B., Walden, G.K. \& Weigend, M. 2016. Familial classification of the Boraginales. Taxon 65: 502-522. http://dx.doi.org/10.12705/653.5

Luo, D., Yue, J.-P., Sun, W.-G., Xu, B., Li, Z.-M., Comes, H.P. \& Sun, H. 2016. Evolutionary history of the subnival flora of the Himalaya-Hengduan Mountains: First insights from comparative phylogeography of four perennial herbs. J. Biogeogr. 43: 31-43. http://dx.doi.org/10.1111/jbi.12610

Mansion, G., Selvi, F., Guggisberg, A. \& Conti, E. 2009. Origin of Mediterranean insular endemics in the Boraginales: Integrative evidence from molecular dating and ancestral area reconstruction. J. Biogeogr. 36: 1282-1296. http://dx.doi.org/10.1111/j.1365-2699.2009.02082.x

Mill, R.R. 1986. A revision of the genus Afrotysonia Rauschert (Boraginaceae). Notes Roy. Bot. Gard. Edinburgh 43: 467-475.

Nazaire, M. \& Hufford, L. 2012. A broad phylogenetic analysis of Boraginaceae: Implications for the relationships of Mertensia. Syst. Bot. 37: 758-783. http://dx.doi.org/10.1600/036364412X648715

Otero, A., Jiménez-Mejía, P., Valcárcel, V. \& Vargas, P. 2014. Molecular phylogenetics and morphology support two new genera (Memoremea and Nihon) of Boraginaceae s.s. Phytotaxa 173: 241-277. http://dx.doi.org/10.11646/phytotaxa.173.4.1

Ovchinnikova, S. 2000. The system of the genus Craniospermum (Boraginaceae). Bot. Zhurn. (Moscow \& Leningrad) 85: 77-87.

Ovchinnikova, S. 2001. Palynomorphology of the genus Craniospermum (Boraginaceae). Bot. Zhurn. (Moscow \& Leningrad) 86: $44-50$.

Ovchinnikova, S. 2007. The system of the tribe Eritrichieae (Boraginaceae). Bot. Zhurn. (Moscow \& Leningrad) 92: 751-759.

Ovchinnikova, S. 2008. Conspectus of the genus Eritrichium (Boraginaceae) species in North Asia. Rastitel'n. Mir Aziatsk. Rossii [= Pl. Life Asian Russia] 2008(1): 17-36.

Ovchinnikova, S. 2009. On the position of the tribe Eritrichieae in the Boraginaceae system. Bot. Serbica 33: 141-146.

Ovchinnikova, S. 2013. The System and conspectus of the genus Anoplocaryum (Boraginaceae) species. Rastitel'n. Mir Aziatsk. Rossii [= Pl. Life Asian Russia] 2013(2): 79-88.

Popov, M.G. 1953. Boraginaceae. Pp. 97-691, 704-718 (addenda) in: Shishkin, B.K. (ed.), Flora of the URSS, vol. 19. Moscow, Leningrad: Izdatel'stvo Akademii Nauk SSSR. [Russian ed.]

Refulio-Rodriguez, N.F. \& Olmstead, R.G. 2014. Phylogeny of Lamiidae. Amer. J. Bot. 101: 287-299. http://dx.doi.org/10.3732/ajb.1300394

Reveal, J.L. 1995-. Indices nominum supragenericorum plantarum vascularium. http://www.plantsystematics.org/reveal/pbio/WWW/ supragen.html (accessed 23 May 2016).

Riedl H. 1963. Anchusa subgen. Chamanchusa subgen. nov. und das System der Borraginoideae-Anchuseae. Österr. Bot. Z. 110: $543-$ 546. http://dx.doi.org/10.1007/BF01441476

Riedl, H. 1967. Boraginaceae. Pp. 1-281 in: Rechinger, K.H. (ed.), Flora Iranica. Graz: Akademische Druck- und Verlagsanstalt.

Riedl, H. 1968. Die neue Tribus Trigonotideae und das System der Boraginoideae. Österr. Bot. Z. 115: 291-321. http://dx.doi.org/10.1007/BF01373311

Riedl, H. 1997. Boraginaceae. Pp. 43-144 in: Kalkman, C., Kirkup, D.W., Nooteboom, H.P., Stevens, P.F. \& De Wilde, W.J.J.O. (eds.), Flora Malesiana, series I, Seed Plants. Leiden: Rijksherbarium/ Hortus Botanicus.

Ripma, L., Simpson, M.G. \& Hasenstab-Lehman, K.E. 2014. Geneious! Simplified genome skimming methods for phylogenetic systematic studies: A case study in Oreocarya (Boraginaceae). Appl. Pl. Sci. 2: 1400062. http://dx.doi.org/10.3732/apps.1400062

Ronquist, F., Teslenko, M., Van der Mark, P., Ayres, D.L., Darling, A., Höhna, S., Larget, B., Liu, L., Suchard, M.A. \& Huelsenbeck, 
J.P. 2012. MrBayes 3.2: Efficient Bayesian phylogenetic inference and model choice across a large model space. Syst. Biol. 61: 539542. http://dx.doi.org/10.1093/sysbio/sys029

Selvi, F., Cecchi, L. \& Coppi, A. 2009. Phylogeny, karyotype evolution and taxonomy of Cerinthe L (Boraginaceae). Taxon 58: 1307-1325.

Selvi, F., Coppi, A. \& Cecchi, L. 2011. High epizoochorous specialization and low DNA sequence variation in Mediterranean Cynoglossum (Boraginaceae): Evidence from fruit traits and ITS region. Taxon 60: 969-985.

Silvestro, D. \& Michalak, I. 2012. raxmlGUI: A graphical front-end for RAxML. Organisms Diversity Evol. 12: 335-337. http://dx.doi.org/10.1007/s13127-011-0056-0

Stamatakis, A. 2014. RAxML version 8: A tool for phylogenetic analysis and post-analysis of large phylogenies. Bioinformatics 30 : 1312-1313. http://dx.doi.org/10.1093/bioinformatics/btu033

Stevens, P.F. 2001-. Angiosperm Phylogeny Website, version 12, July 2012 [and more or less continuously updated since]. http://www. mobot.org/MOBOT/research/APweb/ (accessed 15 Jan 2016).

Thomas, D.C., Weigend, M. \& Hilger, H.H. 2008. Phylogeny and systematics of Lithodora (Boraginaceae, Lithospermeae) and its affinities to the monotypic genera Neatostema, Mairetis, Halacsya and Paramoltkia based on ITS1 and $t r n L^{U A A}$-sequence data and morphology. Taxon 57: 79-97.

Van Royen, P. 1975. Sertulum Papuanum 20. The Boraginaceae of the alpine regions of New Guinea. Pacific Sci. 29: 79-98.

Verdcourt, B. 1991. Boraginaceae. Pp. 1-124 in: Polhill, R.M. (ed.), Flora of tropical East Africa. Rotterdam: Balkema.

Weigend, M., Gottschling, M., Selvi, F. \& Hilger, H.H. 2009. Marbleseeds are gromwells - Systematics and evolution of Lithospermum and allies (Boraginaceae tribe Lithospermeae) based on molecular and morphological data. Molec. Phylogen. Evol. 52: 755-768. http://dx.doi.org/10.1016/j.ympev.2009.05.013

Weigend, M., Gottschling, M., Selvi, F. \& Hilger, H.H. 2010. Fossil and extant Western Hemisphere Boragineae, and the polyphyly of "Trigonotideae" Riedl (Boraginaceae: Boraginoideae). Syst. Bot. 35: 409-419. http://dx.doi.org/10.1600/036364410791638423

Weigend, M., Luebert, F., Selvi, F., Brokamp, G. \& Hilger, H.H. 2013. Multiple origins for Hounds tongues (Cynoglossum L.) and Navel seeds (Omphalodes Mill.) - The phylogeny of the borage family (Boraginaceae s.str.). Molec. Phylogen. Evol. 68: 604-618. http://dx.doi.org/10.1016/j.ympev.2013.04.009

Weigend, M., Luebert, F., Gottschling, M., Couvreur, T.L.P., Hilger, H.H. \& Miller, J.S. 2014. From capsules to nutlets - Phylogenetic relationships in the Boraginales. Cladistics 30: 508-518. http://dx.doi.org/10.1111/cla.12061

Weigend, M., Selvi, F., Thomas, D.C. \& Hilger, H.H. 2016. Boraginaceae. Pp. 41-102 in: Kadereit, J.W. \& Bittrich, V. (eds.), The families and genera of vascular plants, vol. 14, Flowering plants: Eudicots; Aquifoliales, Boraginales, Bruniales, Dipsacales, Escalloniales, Garryales, Paracryphiales, Solanales (except Convolvulaceae), Icacinaceae, Metteniusaceae, Vahliaceae. Cham: Springer International Publishing. http://dx.doi.org/10.1007/978-3-319-28534-4 5

Wiens, J.J. 1998. Combining data sets with different phylogenetic histories. Syst. Biol. 47: 568-581. http://dx.doi.org/10.1080/106351598260581

Zhu, G.-L., Riedl, H. \& Kamelin, R. 1995. Boraginaceae. Pp. 329-427 in: Wu, Z.Y. \& Raven, P.H. (eds.), Flora of China, vol. 16. Beijing: Science Press; St. Louis: Missouri Botanical Garden Press.

Appendix 1. Species included in the phylogenetic analyses of Boraginaceae s.str. with their corresponding vouchers, geographic origins, and GenBank accession numbers (trnL-F; rps16; trnS-G; ITS, respectively). A dash (-) indicates missing sequences. The newly generated sequences are indicated by an asterisk $(*)$.

Actinocarya tibetica Benth., China, Sino-British Qinghai Expedition 1997-658(E), KC542502, KC542666, *KU927867, *KU927641; Adelinia grande (Douglas ex Lehm.) J.I.Cohen, U.S.A., M. Schwarzländer, not vouchered, KC542605, KC542785, *KU927868, *KU927642; Afrotysonia glochidiata (R.R.Mill.) R.R.Mill., South Africa, Bräuchler \& Carbutt 6423 (M), *KU927800, *KU927832, *KU927869, *KU927643; Amblynotus rupestris (Pall.) Popov, Mongolia, Hilger 1597 (BSB), KC542552, KC542730, *KU927870, *KU927644; Amsinckia calycina (Moris) Chater, Peru, Weigend \& Schwarzer 8031 (BSB), GQ285246, KC542699, *KU927871, *KU927645; Amsinckia menziesii A.Nelson \& J.F.Macbr., U.S.A., Weigend 9010 (BSB), KC542579, KC542759, *KU927872, *KU927646; Amsinckia tessellata A.Gray, U.S.A., Hoffmann 4/98 (B), KC542477, KC542626, *KU927873, *KU927647; Amsinckia vernicosa Hook. \& Arn., U.S.A., Weigend 9008 (BSB), KC542581, KC542761, *KU927874, *KU927648; Anchusa formosa Selvi, Bigazzi \& Bacch., Italy, Bigazzi \& Selvi 97.006 (FI), GQ285251, KC542654, *KU927875, GQ285226; Andersonglossum occidentale (A. Gray) J.I.Cohen, U.S.A., Nelson s.n. (USCH), KC542484, KC542641, -, *KU927649; Andersonglossum occidentale (A. Gray) J.I.Cohen, U.S.A., Davis \& Lightowlers 66961 (B), *KU927801, *KU927833, *KU927876, *KU927650; Andersonglossum virginianum (L.) J.I.Cohen, U.S.A., Nelson 21124 (BSB), KC542491, KC542651, *KU927877, *KU927651; Anoplocaryum compressum (Turcz.) Ledeb., Russia, Chan \& Balde s.n. (NSK), *KU927802, *KU927834, *KU927878, *KU927652; Anoplocaryum helenae Volot., Russia, Golajkov s.n. (NSK), *KU927803, *KU927835, *KU927879, *KU927653; Antiphytum floribundum A.Gray, U.S.A., Lott \& al. 5574 (TEX), KC542603, KC542783, *KU927880, *KU927654; Antiphytum hintoniorum L.C.Higgins \& B.L.Turner, Mexico, Patterson \& al. 1415 (TEX), KC542602, KC542782, *KU927881, *KU927655; Arnebia linearifolia DC., Iran, Shahin Zarre \& al. 528 (M), KC542561, KC542739, *KU927882, *KU927656; Asperugo procumbens L., Eurasia, Cult. Berlin, Hilger s.n. (BSB), KC542472, KC542621, *KU927883, *KU927657; Austrocynoglossum latifolium (R.Br.) R.R.Mill, Australia, Cult. Berlin, Weigend 9441 (BSB), KC542618, KC542798, *KU927884, *KU927658; Borago officinalis L., S. Europe, Erixon \& Bremer 11 (UPS), AJ430896, AJ431019, *KU927885, FJ763248; Bothriospermum chinense Bunge, China, A. Yu. Korolyuk, E.A. Korolyuk s.n. (NSK), *KU927804, *KU927836, *KU927886, *KU927659; Bothriospermum tenellum (Hornem.) Fisch. \& C.A.Mey., China, Peng Li ZC-2 (BSB), GQ285272, *KU927837, *KU927887, *KU927660; Bothriospermum tenellum (Hornem.) Fisch. \& C.A.Mey., Japan, Cult. Bot. Gard. Bonn (ID 10691), *KU927805, *KU927838, *KU927888, *KU927661; Brachybotrys paridiformis Maxim. ex Oliv., Russia, Ovchinnikova s.n. (NSK), *KU927806, *KU927839, *KU927889, *KU927662; Brunnera macrophylla (M.Bieb.) I.M.Johnst., Turkey, Hilger s.n. (BSB), GQ285247, KC542644, *KU927890, GQ285223; Buglossoides incrassata (Guss.) I.M.Johnst., Syria, Selvi \& al. 07.40 (FI), KC542553, KC542731, *KU927891, KJ394981; Caccinia macranthera (Banks \& Sol.) Brand, Iran, Shahin Zarre 700 (M), KC542570, KC542748, *KU927892, *KU927663; Caccinia macranthera var. glauca (Savi) Govaerts, Georgia, Lobin \& Weigend 221-1 (M), *KU927807, *KU927840, *KU927893, *KU927664; Caccinia strigosa Boiss., Iran, Mohr M592 (BSB), GQ285241, *KU927841, *KU927894, *KU927665; Cerinthe major L., Tunisia, Bigazzi \& Selvi 04.22 (BSB), FJ763298, KC542690, *KU927895, FJ763244; Chionocharis hookeri I.M.Johnst., Nepal, Crawford \& al. 571 (K), *KU927808, *KU927842, *KU927896, *KU927666; Codon royenii L., South Africa, Greuter 21551 (B), KC542572, KC542750, *KU927897, *KU927667; Codon schenckii Schinz, Namibia, Walter \& Walter 118 (B), GQ285270, KC542751, *KU927898, *KU927668; Craniospermum echioides (Schrenk) Bunge, Mongolia, A.Yu. Korolyuk s.n. (NSK), *KU927809, *KU927843, *KU927899, *KU927669; Craniospermum mongolicum I.M.Johnst., Mongolia, A.Yu. Korolyuk s.n. (NSK), *KU927810, *KU927844, *KU927900, *KU927670; Craniospermum sp. nov., Mongolia, A.Yu. Korolyuk s.n. (NSK), *KU927811, *KU927845, *KU927901, *KU927671; Craniospermum subvillosum Lehm., Russia, Kovtonyuk 741 (NSK), *KU927812, *KU927846, *KU927902, *KU927672; Craniospermum tuvinicum Ovczinnikova, Russia, Chan \& Balde s.n. (NSK), *KU927813, *KU927847, *KU927903, *KU927673; Cryptantha glomerata Lehm. ex G.Don, Chile, Weigend \& Hilger 5935 (BSB), KC542545, KC542722, *KU927904, *KU927674; Cryptantha granulosa I.M.Johnst., Peru, Cult. Berlin, Weigend \& al. 2000/642 (B), KC542527, KC542698, *KU927905, *KU927675; Cryptantha johnstonii L.C.Higgins, U.S.A., Cult. Berlin, Weigend 9007 (BSB), KC542578, KC542758, *KU927906, *KU927676; Cryptantha micrantha (Torr.) I.M.Johnst., U.S.A., Cult. Berlin, Weigend 9058 (BSB), KC542589, KC542769, *KU927907, *KU927677; Cryptantha paradoxa (Nelson) Payson, U.S.A., Cult. Berlin, Weigend 9136 (BSB), KC542580, KC542760, *KU927908, *KU927678; Cryptantha patagonica (Speg.) I.M.Johnst., Argentina, Weigend \& al. 
Appendix 1. Continued.

5957 (BSB), GQ285256, KC542657, *KU927909, *KU927679; Cryptantha pterocarya (Torr.) Greene, U.S.A., Fahl H20a/1998 (BSB), EU600017 EU599929, KC542721, *KU927910, *KU927680; Cryptantha texana (A.DC.) Greene, U.S.A., Carr 25514 (TEX), KC542601, KC542781, *KU927911, *KU927681; Cynoglossum amabile Stapf \& J.R.Drumm., Ecuador (introduced), Cult. Bot. Gard. Bonn, Joßberger P663 (BONN), *KU927814, *KU927848, *KU927912, *KU927682; Cynoglossum amabile Stapf \& J.R.Drumm., Cult. Bot. Gard. Bonn, Joßberger, P402 (BONN), *KU927815, *KU927849, *KU927913, *KU927683; Cynoglossum amplifolium Hochst. ex A.DC., Kenya, Cult. Bot. Gard. Bonn, Koelker 06 (B), *KU927816, *KU927850, *KU927914, *KU927684; Cynoglossum australe R.Br., Australia, Cult. Bot. Gard. Bonn, Joßberger P648 (BONN), *KU927817, *KU927851, *KU927915, *KU927685; Cynoglossum clandestinum Desf., Tunisia, Bigazzi \& Selvi 04.21 (FI), KC542522, KC542689, *KU927916, *KU927686; Cynoglossum coeruleum A.DC., Kenya, Cult. Bot. Gard. Bonn (ID 34835), *KU927818, *KU927852, *KU927917, *KU927687; Cynoglossum columnae Ten., Greece, Hilger 98/7 (BSB), KC542478, KC542627, *KU927918, *KU927688; Cynoglossum creticum Mill., Greece, Hilger 98/9 (BSB), KC542479, KC542628, *KU927919, *KU927689; Cynoglossum dioscoridis Vill., Morocco, Bigazzi \& Selvi 05.33 (FI), KC542524, KC542693, *KU927920, *KU927690; Cynoglossum germanicum Jacq., Germany, Hilger s.n. (BSB), GQ285245, KC542635, *KU927921, *KU927691; Cynoglossum lanceolatum Forssk., Swaziland, Cult. Berlin, Weigend 9198 (B), *KU927819, *KU927853, *KU927922, *KU927692; Cynoglossum magellense Ten., Italy, Bigazzi \& Selvi 03.05 (FI), KC542519, KC542685, *KU927923, *KU927693; Cynoglossum montanum L., Hungary, Hilger 97/17 (BSB), KC542480, KC542629, *KU927924, *KU927694; Cynoglossum montanum subsp. extraeuropaeum Brand, Turkey, Bigazzi \& Selvi 02.23 (FI), KC542517, KC542683, *KU927925, *KU927695; Cynoglossum officinale L., U.S.A., Hilger s.n. (BSB), GQ285248, KC542645, *KU927926, *KU927696; Cynoglossum pauciflorum Ruiz \& Pav., Chile, Kern 14.12.2009 (CONC), *KU927820, *KU927854, *KU927927, *KU927697; Cynoglossum sphacioticum Boiss. \& Heldr., Greece, Hilger s.n. (BSB), KC542509, KC542675, *KU927928, *KU927698; Cynoglossum suaveolens R.Br., Australia, Lepschi \& Craven 3937 (CANB), KC542518, KC542684, *KU927929, *KU927699; Cynoglossum troodi H.Lindb., Cyprus, Brullo \& al. s.n. (FI, CAT), KC542495, KC542656, *KU927930, *KU927700; Cystostemon ethiopicus A.G.Mill. \& Riedl, Ethiopia, Thulin \& al. 3576 (UPS), KC542597, KC542777, *KU927931, *KU927701; Cystostemon hispidus (Baker \& Wright) A.G.Mill \& Riedl, Kenya, Forstreuter 91702 (BSB), KC542594, KC542774, *KU927932, *KU927702; Dasynotus daubenmirei I.M.Johnst., U.S.A., Crockett 492 (IDAHO), KC542535, KC542711, *KU927933, *KU927703; Dasynotus daubenmirei I.M.Johnst., U.S.A., Schwarzländer s.n. (not vouchered), KC542604, KC542784, *KU927934, *KU927704; Decalepidanthus elongatus (Decne.) Dickoré \& Hilger, Pakistan, Nüsser 874 (B), - , *KU927855, -, *KU927705; Decalepidanthus primuloides (Decne.) Dickoré \& Hilger, Pakistan, Cult. Berlin, M. Ackermann s.n. ED19751894 (BSB), ${ }^{*}$ KU927821, *KU927856, *KU927935, *KU927706; Decalepidanthus trollii (Melch.) Dickoré \& Hilger, India, Cult. Edinburgh, Sherriff s.n. ED19391024 (E), KC542593, KC542773, *KU927936, -; Echiochilon fruticosum Desf., Libya, Kagiampaki s.n. (BSB), FJ763310, KC542756, *KU927939, *KU927708; Echium callithyrsum Webb ex Bolle, Spain, Hilger 92/3482 (BSB), KC542532, KC542707, *KU927937, *KU927707; Echium creticum L., Italy, Förther s.n. (BSB), FJ763303, KC542706, *KU927938, FJ763249; Echium vulgare L., Germany, Mohr 597 (BSB), FJ763301, KC542705, *KU927940, FJ763247; Eritrichium aretioides (Cham.) DC., U.S.A., Weigend 9126 (BSB), KC542591, KC542771, *KU927941, *KU927709; Eritrichium canum (Benth.) Kitam., Russia, Förther s.n. (M), GQ285242, KC542631, *KU927942, *KU927710; Eritrichium nanum (L.) Schrad. Ex Gaudin, Switzerland, Zippel \& al. s.n. (B), KC542483, KC542640, *KU927943, *KU927711; Eritrichium pamiricum B.Fedtsch., Afghanistan, Anders 8098 (M), KC542564, KC542742, *KU927944, *KU927712; Eritrichium pectinatociliatum Y.S.Lian \& J.Q. Wang, China, Boufford \& al. 29997 (B), KC542611, KC542791, *KU927945, *KU927713; Glandora nitida (Ern) D.C.Thomas, Spain, Thomas 1-05 (BSB), FJ763299, KC542691, FJ763333, FJ763245; Hackelia bella (J.F.Macbr.) I.M.Johnst., U.S.A., Merello \& al. 702 (MO), KC542497, KC542660, *KU927947, *KU927715; Hackelia cf. andicola (K.Krause) Brand, Ecuador, Weigend \& Brokamp 8847 (BSB), KC542565, KC542743, *KU927946, *KU927714; Hackelia deflexa (Wahlenb.) Opiz, Italy, Frey s.n. (BSB), GQ285244, KC542634, *KU927948, *KU927716; Hackelia sharsmithii I.M.Johnst., U.S.A., Hilger U.S.A. 94/18 (BSB), KC542498, KC542661, *KU927949, *KU927717; Hackelia thymifolia (A.DC.) I.M.Johnst., Mongolia, Hurka 10234 (OSBU), KC542575, KC542754, *KU927950, *KU927718; Hackelia velutina (Piper) I.M.Johnst., U.S.A., Hilger 411/1997(BSB), KC542530, KC542702, *KU927951, *KU927719; Harpagonella palmeri A.Gray, U.S.A., Weigend 9056 (BSB), KC542590, KC542770, *KU927952, *KU927720; Heterocaryum subsessile Vatke, Afghanistan, Rechinger 33789 (B), KC542573, KC542752, *KU927953, *KU927721; Lappula marginata Gürke, Mongolia, Hilger 1616 (BSB), KC542576, KC542755, *KU927954, *KU927722; Lappula occidentalis (S.Watson) Greene, U.S.A., Hilger 96/2 (BSB), KC542496, KC542659, *KU927955, *KU927723; Lappula sessiliflora (Boiss.) Gürke, Turkey, Bigazzi \& Selvi 02.35 (FI), KC542512, KC542678, *KU927956, *KU927724; Lappula shanhsiensis Kitag., China, Kürschner \& al. 634 (BSB), KC542543, KC542719, *KU927957, *KU927725; Lappula squarrosa (Retz.) Dumort., Germany, Mohr 591 (BSB), GQ285265, KC542704, *KU927958, *KU927726; Lasiocaryum munroi (C.B.Clarke) I.M.Johnst., India, Poelt 276 (M), KC542562, KC542740, *KU927959, *KU927727; Lasiocaryum trichocarpum (Hand.-Mazz.) I.M.Johnst., Bhutan, Sinclair \& Long 5405 (E), KC542582, KC542762, *KU927960, *KU927728; Lindelofia longifolia (Benth.) Baill., Himalaya, Weigend 9120 (BSB), KC542489, KC542648, *KU927961, *KU927729; Lindelofia macrostyla (Bunge) Popov, China, Vasak s.n. (M), *KU927822, *KU927857, *KU927962, *KU927730; Lindelofia olgae Brand, former USSR, Kaletkina s.n. 17.06.1966 (M), *KU927823, *KU927858, *KU927963, *KU927731; Lithospermum macbridei I.M.Johnst., Peru, Weigend \& al. 5073 (BSB), FJ763273, HQ286268, FJ763320, FJ763213; Lithospermum officinale L., Germany, Werres \& Ristow s.n. (BSB), FJ763254, KC542633, FJ763311, FJ763189; Lithospermum peruvianum A.DC., Peru, Weigend \& al. $2000 / 761$ (M), FJ763276, KC542658, FJ763322, FJ763217; Lithospermum tschimganicum B.Fedtsch., Kazakhstan, Orazowa \& Fissjun 5785 (B), FJ763279, HQ286267, FJ763323, FJ763220; Lycopsis arvensis L., Germany, Hilger \& Werres s.n. (BSB), KC542485, KC542642, *KU927964, *KU927732; Mairetis microsperma (Boiss.) I.M.Johnst., Morocco, Podlech 48277 (MSB), FJ763257, KC542636, *KU927965, FJ763193; Mattiastrum lithospermifolium (Lam.) Brand, Turkey, Bergmeier \& Matthäs 3422 (B), KC542595, KC542775, *KU927966, *KU927733; Memoremea scorpioides (Haenke) Otero, Jim.-Mejías, Valcá rcel \& P. Vargas, Germany, Weigend 9039 (BSB), KC542584, KC542764, *KU927967, *KU927734; Mertensia ciliata (Torrey) G.Don, U.S.A., Ackermann 709 (BSB), KC542596, KC542776, *KU927968, *KU927735; Mertensia dahurica G.Don, Mongolia, Hilger 1601 (BSB), KC542592, KC542772, *KU927969, *KU927736; Mertensia lanceolata DC., U.S.A., Weigend 9171 (BSB), KC542607, KC542787, *KU927970, *KU927737; Mertensia maritima (L.) Gray, UK, Hilger s.n. (BSB), GQ285259, KC542673, *KU927971, *KU927738; Mertensia sibirica G.Don, Russia, Weigend 9069 (BSB), KC542586, KC542766, *KU927972, *KU927739; Metaeritrichium microuloides W.T.Wang, China, Boufford \& al. 32025 (B), KC542612, KC542792, *KU927973, *KU927740; Microcaryum pygmaeum (C.B.Clarke) I.M.Johnst., China, Boufford \& al. 36208 (B), KC542610, KC542790, *KU927977, *KU927744; Microparacaryum intermedium (Fresen.) Hilger \& Podlech, Saudi Arabia, Kürschner 10-52 (Herb. Kürschner), KC542606, KC542786, *KU927975, *KU927742; Microula filicaulis W.T.Wang, China, Boufford 40060 (B, HUH), *KU927824, *KU927859, *KU927974, *KU927741; Microula pustulosa (C.B.Clarke) Duthie, China, Sino-American-British Yushu Expedition (1996) 2328 (E), KC542499, KC542663, *KU927976, *KU927743; Microula stenophylla W.T. Wang, China, Zang \& al. 121 (BONN), *KU927825, *KU927860, *KU927978, *KU927745; Moltkia petraea (Tratt.) Griseb., Turkey, Hilger s.n. (BSB), FJ763258, KC542637, *KU927979, FJ763194; Moritzia lindenii Benth. ex Guerke, Ecuador, Eriksen 59018 (MO), KC542531, KC542703, *KU927980, GQ285231; Myosotidium hortensia (Decne.) Baill., New Zealand, Hilger s.n. (M), KC542488, KC542647, *KU927981, *KU927746; Myosotidium hortensia (Decne.) Baill., New Zealand, Weigend 9068 (BSB), KC542587, KC542767, *KU927982, *KU927747; Myosotis caespitosa DC., Finland, Hilger 1575 (BSB), GQ285262, KC542696, *KU927983, *KU927748; Myosotis incrassata Guss., Greece, Hilger 98/5 (BSB), GQ285243, KC542632, *KU927984, *KU927749; Myosotis sparsiflora J.C.Mikan ex Pohl, Czech Republic, Weigend 8138 (BSB), GQ285239, KC542620, *KU927985, *KU927750; Myosotis stenophylla Knaf ex Vestergr., Czech Republic, Mohr 614 (BSB), KC542537, KC542713, *KU927986, *KU927751; Myosotis stolonifera J.Gay, UK, Hilger s.n. (BSB), GQ285258, KC542672, *KU927987, *KU927752; Nihon akiense (Kadota) Otero, Jim.-Mejías, Valcárcel \& P. Vargas, Japan, Suga s.n. (B), KC542616, KC542796, *KU927988, *KU927753; Nihon japonicum (Thunb.) Otero, Jim.-Mejías, Valcárcel \& P. Vargas, Japan, Kubota s.n. (TNS, B, M), *KU927826, *KU927861, *KU927989, *KU927754; Omphalodes aliena A.Gray ex Hemsl., Mexico, Hinton 28565 (TEX), KC542600, KC542780, *KU927990, *KU927755; Omphalodes cappadocica (Willd.) DC., Caucasus, Cult. Berlin, Weigend 8196 (BSB), KC542525, KC542694, *KU927991, *KU927756; Omphalodes caucasica Brand, Caucasus, Cult. Munich, Anon anno 1969 (M), KC542559, KC542737, *KU927992, *KU927757; Omphalodes commutata G.López, Spain, Hilger s.n. (BSB), KC542542, KC542718, *KU927993, *KU927758; Omphalodes kuzinskyanae Willk., Portugal, Mohr 611 (BSB), KC542608, KC542788, *KU927994, *KU927759; Omphalodes linifolia (L.) Moench, Spain, Hilger 
Appendix 1. Continued.

s.n. (BSB), KC542494, KC542655, *KU927995, *KU927760; Omphalodes verna Moench, Italy, Hilger s.n. (BSB), KC542486, KC542643, *KU927996, *KU927761; Onosma barsczewskii Lipsky, Tajikistan, Ovchinnikova 157 (NSK), *KU927827, *KU927862, *KU927997, *KU927762; Onosma rhodopaea Velen., Bulgaria, Hilger 97/24 (BSB), FJ763259, KC542639, *KU927998, FJ763195; Onosma tricerosperma Lag., Spain, Hilger s.n. (BSB), KC542541, KC542717, *KU927999, *KU927763; Paracaryum ancyritanum Boiss., Turkey, Bigazzi \& Selvi 02.39 (FI), KC542511, KC542677, *KU928000, *KU927764; Paracaryum cappadocicum Boiss. \& Balansa, Turkey, Bigazzi \& Selvi 02.41 (FI), KC542508, KC542674, *KU928001, *KU927765; Paracaryum racemosum (Schreb.) Britten, Turkey, Tarikahya 1537a (BSB), KC542536, KC542712, *KU928002, *KU927766; Paracaryum rugulosum (DC.) Boiss., Turkey, Bigazzi \& Selvi 02.42 ( FI), KC542516, KC542682, *KU928003, *KU927767; Paracynoglossum asperrimum (Nakai) Popov, Russia, Mohr 615 (BSB), KC542538, KC542714, *KU928004, *KU927768; Pardoglossum cheirifolium (L.) Barbier \& Mathez, Tunisia, Bigazzi \& Selvi 04.25 (FI), KC542523, KC542692, *KU928005, *KU927769; Pectocarya lateriflora (Lam.) DC., Peru, Weigend \& Schwarzer 7810 (BSB), KC 542529, KC542701, *KU928006, *KU927770; Pectocarya penicillata (Hook. \& Arn.) A.DC., U.S.A., Fahl H19/1998 (BSB), KC542549, KC542727, *KU928007, *KU927771; Pectocarya setosa A.Gray, U.S.A., Hilger 14/1998 (BSB), KC542528, KC542700, *KU928008, *KU927772; Pentaglottis sempervirens (L.) L.H.Bailey, Spain, Selvi \& Bigazzi 6/2000 (FI), KC542490, KC542650, *KU928009, GQ285225; Plagiobothrys congestus (Wedd.) I.M.Johnst., Bolivia, Villavicencio s.n. (B), KC542546, KC542723, *KU928010, *KU927773; Plagiobothrys humilis (Ruiz \& Pav.) I.M.Johnst., Peru, Weigend \& Schwarzer 8075 (BSB), GQ285269, KC542724, *KU928011, *KU927774; Plagiobothrys kunthii (Walp.) I.M.Johnst., Peru, Weigend \& Schwarzer 7832 (BSB), KC542548, KC542726, *KU928012, *KU927775; Plagiobothrys linifolius (Willd. ex Lehm.) I.M.Johnst., Peru, Schwarzer 04 (BSB), KC542547, KC542725, *KU928013, *KU927776; Plagiobothrys myosotoides (Lehm.) Brand, Peru, Weigend \& Schwarzer 7825 (BSB), KC542520, KC542687, *KU928014, *KU927777; Pulmonaria angustifolia L., Italy, M. \& K. Weigend 1999/45 (BSB), GQ285266, KC542709, *KU928015, GQ285232; Rindera schlumbergeri (Boiss.) Gürke, Syria, Selvi \& al. 07.32 (FI), KC542554, KC542732, *KU928016, *KU927778; Rindera tetraspis Pallas, Russia, Sagalaev \& Rusanovich 18328 (B), KC542493, KC542653, *KU928017, *KU927779; Rochelia cancellata Boiss. \& Balansa, Turkey, Bigazzi \& Selvi 02.53 (BSB), KC542514, KC542680, *KU928018, *KU927780; Rochelia cardiosepala Bunge, Turkey, Bigazzi \& Selvi 02.61 (BSB), KC542515, KC542681, *KU928019, *KU927781; Rochelia persica Bunge ex Boiss., Iraq, Rechinger 10377 (B), KC542577, KC542757, *KU928020, *KU927782; Solenanthus apenninus (L.) Fisch. \& C.A.Mey, Italy, Frey s.n. (BSB), KC542487, KC542646, *KU928021, *KU927783; Solenanthus tubiflorus Murb., Tunisia, Bigazzi \& Selvi 04.23 (FI), KC542521, KC542688, *KU928022, *KU927784; Suchtelenia calycina (C.A.Mey.) A.DC., Azerbaijan, Parolly \& al. 13080 (B), KC542617, KC542797, *KU928023, *KU927785; Symphytum cordatum Waldst. \& Kit., Caucasus, Cult. Berlin, Weigend 8047 (BSB), KC542598, KC542778, *KU928024, *KU927786; Symphytum grandiflorum DC., Caucasus, Cult. Berlin, Weigend 9034 (BSB), KC542599, KC542779, *KU928025, *KU927787; Thyrocarpus sampsonii Nance, China, Liu Zheng-yu 15360 (E), *KU927828, *KU927863, *KU928026, *KU927788; Trachelanthus cerinthoides (Boiss.) O.Kunze, Iran, Parishani 14275 (M), KC542560, KC542738, *KU928027, *KU927789; Trachystemon orientalis (L.) G.Don, Caucasus, Cult. Berlin, Weigend 9030 (BSB), GQ285249, KC542649, *KU928028, GQ285224; Trichodesma africanum (L.) Sm., Algeria, Podlech 35050 (M), KC542568, KC542746, *KU928029, *KU927790; Trichodesma calcaratum Coss., Morocco, Podlech 41053 (M), KC542567, KC542745, *KU928030, *KU927791; Trichodesma zeylanicum (Burm.f.) R.Br., Kenya, Schultka 12 (BSB), GQ285240, KC542623, *KU928031, *KU927792; Trigonocaryum involucratum (Stev.) Kusn., Georgia, Gröger \& al. 213-20 (M), *KU927829, *KU927864, *KU928032, *KU927793; Trigonotis formosana var. elevatovenosa (Hayata) S.D. Shen \& J.C.Wang, Taiwan, Cult. Berlin, Weigend 8128 (BSB), GQ285261, KC542695, *KU928033, *KU927794; Trigonotis guilielmi (A.Gray) Guerke, Japan, Azuma 2001 (BSB), GQ285257, KC542662, *KU928034, *KU927795; Trigonotis jinfoshanica W.T.Wang, China, Peng Li ZC-?-2 (HUH), KC542583, KC542763, *KU928035, *KU927796; Trigonotis radicans (Tucz.) Stev., Russia, Starczenko \& Ivanova 5488 (M), *KU927830, *KU927865, *KU928036, *KU927797; Wellstedia socotrana Balf.f., Somalia, Thulin \& al. 10155 (UPS), KC542615, KC542795, *KU928037, *KU927798; Wellstedia somalensis Thulin \& A.Johanss., Somalia, Thulin \& al. 10084 (UPPS), *KU927831, *KU927866, *KU928038, *KU927799 